\title{
Effects of glucogenic and ketogenic feeding strategies on splanchnic glucose and amino acid metabolism in postpartum transition Holstein cows
}

\author{
M. Larsen ${ }^{1}$ and N. B. Kristensen ${ }^{2}$ \\ Department of Animal Science, Aarhus University, Foulum, DK-8830 Tjele, Denmark
}

\begin{abstract}
Nine periparturient Holstein cows catheterized in major splanchnic vessels were used in a complete randomized design with repeated measurements to investigate effects of glucogenic and ketogenic feeding strategies on splanchnic metabolism of glucose and amino acids. At parturition, cows were assigned to 1 of 3 feeding strategies: a glucogenic diet (GLCG) based on sodium hydroxide treated wheat grain ( $56.5 \%$ of diet dry matter); a ketogenic diet (KETO) based on fodder beets (40.5\% of diet dry matter); or an alfalfa-glucogenic strategy (ALF-GLCG) supplying 100\% alfalfa (Medicago sativa L.) haylage at the day of parturition, followed by a $6-\mathrm{d}$ linear shift to the GLCG diet. Samples were obtained $14 \mathrm{~d}$ before expected parturition as well as at 4,15, and $29 \mathrm{~d}$ in milk (DIM). The net portal release of glucose was greatest with GLCG, reflecting the higher intake of ruminal escape starch with GLCG, as compared with a lower starch intake with KETO. Postpartum, the portal recovery of feed starch was greater $(28 \pm 3 \%$, mean \pm SEM) with KETO as compared with GLCG $(15 \pm 4 \%)$. At 4 DIM, the net hepatic release of glucose was greatest with KETO and least with ALF-GLCG, whereafter it increased as lactation progressed with ALF-GLCG and GLCG, but not with KETO. The high alfalfa haylage allowance at 4 DIM with the ALF-GLCG treatment induced the lowest net release of nutrients from the splanchnic tissues at 4 DIM. The hepatic removal of lactate as percent of total influx (mean \pm SEM) increased from $27 \pm 3 \%$ prepartum to $56 \pm 3 \%$ at 4 DIM. The hepatic removal of lactate as percent of net portal release increased from $144 \pm 10 \%$ prepartum to $329 \pm 17 \%$ at 4 DIM with ALF-GLCG and KETO as compared with $242 \pm 20 \%$ in GLCG. No clear evidence for an amino acid sparing effect in splanchnic tissues from increasing small intestinal glucose absorption was observed. In conclusion, the glucogenic feeding strategy induced the highest glucogenic status among the tested
\end{abstract}

\footnotetext{
Received February 22, 2012.

Accepted June 26, 2012.

${ }^{1}$ Corresponding author: Mogens.Larsen@agrsci.dk

${ }^{2}$ Current address: Syddansk Kvæg, Billundvej 3, DK-6500 Vojens, Denmark.
}

feeding strategies due to greater release of glucose from splanchnic tissues. In contrast, the immediate postpartum high allowance of alfalfa haylage provided the lowest amount of nutrients from the splanchnic tissues, inducing low glucogenic status, pointing to the importance of allocating highly digestible diets to postpartum transition cows. Salvaging glucogenic carbon via interorgan transfer of lactate from peripheral tissues supported the immediate postpartum incremental increase in hepatic glucose release rather than hepatic catabolism of amino acids.

Key words: periparturient dairy cow, glucose, amino acid, gluconeogenesis

\section{INTRODUCTION}

The whole-body demand for glucose and AA increase abruptly at parturition when mammary lactose and protein synthesis increases from virtually none to around $1 \mathrm{~kg} / \mathrm{d}$ of each within few days after calving (Bell, 1995; Drackley et al., 2001). The contemporary increase in feed intake is not sufficient to meet the increased demand for nutrients (Overton, 1998; Drackley et al., 2001). Even though hepatic glucose release increases rapidly after parturition (Reynolds et al., 2003; Larsen and Kristensen, 2009b), periparturient cows often suffer from hypoglycemic-hyperketonemic conditions, with potentially negative implications for health, production, and overall wellbeing of cows (Grummer, 1995).

Increasing the glucogenic status of periparturient cows could be a way to obtain an endocrine status favoring less mobilization; thus, feeding diets that increase small intestinal glucose absorption could be safe and attractive strategies to obtain both increased direct exogenous glucose supply and decreased fat mobilization. Larsen and Kristensen (2009b) recently observed that glucose infused into the abomasum was efficiently transferred to peripheral tissues in postpartum transition cows, leading to an overall increased glucogenic status and decreased NEFA levels. However, it is unknown to what extent these effects can be obtained with diets applicable under field conditions. The efficacy of increasing the peripheral tissue supply of glucose via small intestinal 
glucose absorption depends on the capacity for starch hydrolysis, absorption capacity, and the metabolic response of splanchnic tissues (Harmon et al., 2004). One often-discussed metabolic response to increased glucose absorption from the small intestine is the potential for sparing AA from catabolism for energetic and glucogenic purposes in portal-drained visceral (PDV) and hepatic tissues (Nocek and Tamminga, 1991; Freetly et al., 2010). In postpartum transition cows, it has further been hypothesized that the rapidly increasing glucose demand postpartum is supported by increased utilization of glucogenic AA for hepatic gluconeogenesis (Overton, 1998; Drackley et al., 2001). This hypothesis has, however, been questioned in recent investigations using splanchnic catheterized periparturient dairy cows (Reynolds et al., 2003; Larsen and Kristensen, 2009a), which report that no AA, except Ala, appear to contribute significantly to hepatic glucose release in the early postpartum period.

The overall objective of the present study was to investigate the effect of practical applicable glucogenic and ketogenic feeding strategies on splanchnic nutrient metabolism and metabolic adaptation in periparturient dairy cows. We hypothesized that increased supply of ruminal escape starch to postpartum transition dairy cows would increase PDV and net splanchnic release of glucose, but not affect PDV and net splanchnic release of essential AA (EAA).

\section{MATERIALS AND METHODS}

The present experiment complied with Danish Ministry of Justice Law no. 382 (June 10, 1987), Act no. 726 (September 9, 1993), concerning experiments with animals and care of experimental animals.

\section{Animals and Experimental Design}

Nine Danish Holstein cows entering their second lactation were used in a complete randomized design with repeated measurements. Cows were randomly assigned to 1 of 3 feeding strategies initiated at the day of parturition: a glucogenic strategy (GLCG) based on sodium hydroxide-treated wheat grain $(56.5 \%$ of $\mathrm{DM}$; Table 1); a ketogenic diet (KETO) based on fodder beets (40.5\% of DM); or an alfalfa-glucogenic strategy (ALF-GLCG) with allocation of 100\% unchopped alfalfa (Medicago sativa L.) haylage at the day of parturition, followed by a 6-d linear shift to the GLCG diet. Sodium hydroxide-treated wheat grain was prepared in a mixer wagon by adding $30 \mathrm{~kg}$ of $\mathrm{NaOH}$ to 1,000 $\mathrm{kg}$ of wheat, mixed for 5 min before adding $103 \mathrm{~kg}$ of water, mixed for $15 \mathrm{~min}$ before placing in a pile for $5 \mathrm{~h}$, and spread on concrete to a depth of $20 \mathrm{~cm}$ for cooling. After cooling, the $\mathrm{NaOH}$-treated wheat grain was stored in dosing silos and a minimum of $4 \mathrm{~d}$ was allowed between preparation and feeding. The chemical composition of alfalfa haylage was $69.6 \%$ DM, 92 $\mathrm{g}$ of $\mathrm{ash} / \mathrm{kg}$ of DM, $158 \mathrm{~g}$ of $\mathrm{CP} / \mathrm{kg}$ of DM, and $440 \mathrm{~g}$ of NDF $/ \mathrm{kg}$ of DM. Samplings were scheduled on $14 \mathrm{~d}$ before expected parturition as well as on 4, 15, and 29 DIM. All cows received the same prepartum diet composed to fulfill the Nordic recommendation for nutrient allowances (Volden, 2011) at restricted intake of $10 \mathrm{~kg}$ of $\mathrm{DM} / \mathrm{d}$. Postpartum, treatment diets were offered ad libitum (10\% orts). Diets were fed 3 times daily at 0800,1600 , and $2400 \mathrm{~h}$ in equally sized meals and orts were removed at $0730 \mathrm{~h}$. Cows had permanent free access to water and salt mineral blocks (Salto Kvæg; Vitfoss A/S, Gråsten, Denmark). Cows were milked 3 times daily at 0600, 1400, and $2200 \mathrm{~h}$.

Cows were implanted with a ruminal cannula at dryoff 9 wk before expected parturition. Two to 3 wk later, permanent indwelling catheters were implanted in the mesenteric artery, mesenteric vein, hepatic portal vein, and hepatic vein (Kristensen et al., 2007) and in the right ruminal vein (Kristensen et al., 2010). In case the mesenteric artery catheter lost patency, a catheter was implanted in an intercostal artery (Larsen and Kristensen, 2009b). Cows were housed in tie-stalls bedded with rubber mats and wood shavings, and were moved to a straw-bedded pen for calving.

\section{Experimental Samplings and Data Collection}

Eight hourly sample sets of arterial, portal venous, and hepatic venous blood were collected simultaneously starting $30 \mathrm{~min}$ before feeding at $0800 \mathrm{~h}$. Before blood sampling, catheters were primed by drawing and discarding a minimum of 2 times the catheter volume. Before collecting the main samples, whole blood samples were collected for immediate blood gas and oximetry measurements using heparinized 2-mL gas syringes (PICO50; Radiometer A/S, Copenhagen, Denmark). Samples were immediately placed on crushed ice. The main arterial, portal, and hepatic blood samples were drawn simultaneously using $20-\mathrm{mL}$ disposable syringes and the blood was immediately transferred to heparin or $\mathrm{K}_{3}$ EDTA vacuettes (no. 455051 and 455036, respectively; Greiner Bio-One GmbH, Kremsmünster, Austria). Vacuettes were placed on crushed ice immediately after sampling. Plasma was harvested by centrifugation at $3,000 \times g$ for $20 \mathrm{~min}$ at $4^{\circ} \mathrm{C}$. Blood plasma samples were stored at $-20^{\circ} \mathrm{C}$ until analysis. Blood plasma flow was measured by downstream dilution of $p$-aminohippuric acid (pAH) continuously infused $(30.0 \pm 0.4$ $\mathrm{mmol} / \mathrm{h}$, mean $\pm \mathrm{SE}$ ) into the mesenteric vein initiated at least 60 min before first blood sampling using silicone 
Table 1. Diet compositions ( $\mathrm{g} / \mathrm{kg}$ of DM, unless otherwise noted)

\begin{tabular}{|c|c|c|c|}
\hline \multirow[b]{2}{*}{ Item } & \multirow[b]{2}{*}{ Prepartum } & \multicolumn{2}{|c|}{ Postpartum $^{1}$} \\
\hline & & GLCG & KETO \\
\hline \multicolumn{4}{|l|}{ Ingredient } \\
\hline Corn silage $^{2}$ & 450 & & \\
\hline Grass-clover silage & $200^{3}$ & $257.5^{4}$ & $257.5^{4}$ \\
\hline Barley straw & 118 & & \\
\hline Wheat, ground & 100 & & \\
\hline Wheat, $\mathrm{NaOH}$ treated & & 565 & 150 \\
\hline Fodder beets ${ }^{5}$ & & & 405 \\
\hline Soybean meal, $54 \%$ CP & 100 & & \\
\hline SoyPass ${ }^{6}$ & & 91.5 & 91.5 \\
\hline Corn gluten, $68 \% \mathrm{CP}$ & & 50 & 50 \\
\hline Urea & & & 5.0 \\
\hline Molasses, sugar cane & 10 & & \\
\hline Vegetable fat $^{7}$ & 7.5 & 10 & 10 \\
\hline Premixes & $12^{8}$ & $11^{9,10}$ & $11^{9,10}$ \\
\hline $\mathrm{CaCO}_{3}$ & & 7.5 & 7.5 \\
\hline $\mathrm{NaCl}$ & 2.5 & & \\
\hline $\mathrm{NaHCO}_{3}$ & & & 5.0 \\
\hline $\mathrm{Mg}_{3}\left(\mathrm{PO}_{4}\right)_{3}$ & & 5.0 & 5.0 \\
\hline $\mathrm{Na}_{2} \mathrm{SO}_{4}$ & & 1.5 & 1.5 \\
\hline $\mathrm{Cr}_{2}(\mathrm{III}) \mathrm{O}_{3}$ & & 1.0 & 1.0 \\
\hline \multicolumn{4}{|l|}{ Nutrient } \\
\hline Ash & 68 & 86 & 101 \\
\hline $\mathrm{CP}$ & 155 & 181 & 187 \\
\hline Starch & 180 & 369 & 107 \\
\hline Sugars & 36 & 50 & 284 \\
\hline $\mathrm{NDF}$ & 336 & 157 & 162 \\
\hline $\mathrm{MP}^{11}$ & 74 & 108 & 104 \\
\hline $\mathrm{NE}_{\mathrm{J}}{ }^{11} \mathrm{MJ} / \mathrm{kg}$ of DM & 6.78 & 7.69 & 7.08 \\
\hline
\end{tabular}

${ }^{1} \mathrm{GLCG}=$ glucogenic diet; KETO = ketogenic diet.

${ }^{2}$ Chemical analysis: DM, 31.5\%; ash $2.9 \%$ of DM; CP, $7.9 \%$ of DM; NDF , $37.7 \%$ of DM; starch, $22.7 \%$ of DM; and in vitro digestible OM, $74.4 \%$ of DM.

${ }^{3}$ Chemical analysis: DM, $46.5 \%$; ash $7.8 \%$ of DM; CP, $17.2 \%$ of DM; NDF, $37.1 \%$ of DM; sugars, $7.2 \%$ of DM; and in vitro digestible OM, $74.3 \%$ of DM.

${ }^{4}$ Chemical analysis: DM, $39.7 \%$; ash $4.7 \%$ of DM; CP, $16.3 \%$ of DM; $\mathrm{NDF}, 32.2 \%$ of DM; sugars, $9.3 \%$ of DM; and in vitro digestible OM, $81.6 \%$ of DM.

${ }^{5}$ Chemical analysis: DM, $16.0 \%$; ash, $9.4 \%$ of DM; CP, $7.8 \%$ of DM; sugars, $60.4 \%$ of DM; and NDF, $10.5 \%$ of DM.

${ }^{6}$ Rumen-protected soybean meal (Borregaard LignoTech, Sarpsborg, Norway).

${ }^{7}$ Palm FA distillate (PFAD; Scanfedt A/S, Fredericia, Denmark).

${ }^{8}$ Dry premix (Gold d-alfa Bio org. Selen; Vitfoss, Gråsten, Denmark) containing (per kilogram): $20 \mathrm{~g}$ of Ca, $50 \mathrm{~g}$ of $\mathrm{P}, 140 \mathrm{~g}$ of $\mathrm{Mg}, 9 \mathrm{~g}$ of $\mathrm{Na}, 6 \mathrm{~g}$ of S, $600 \mathrm{kIU}$ of vitamin A, $190 \mathrm{kIU}$ of vitamin D, $18,182 \mathrm{mg}$ of $R R R$ - $\alpha$-tocopherol, 4,000 $\mathrm{mg}$ of $\mathrm{Mn}, 1,500 \mathrm{mg}$ of $\mathrm{Cu}, 25 \mathrm{mg}$ of $\mathrm{Co}$, $4,500 \mathrm{mg}$ of Zn, $225 \mathrm{mg}$ of I, $24 \mathrm{mg}$ of organic Se, and $24 \mathrm{mg}$ of Se.

${ }^{9}$ Lactation premix (VM 1; Vitfoss) containing (per kilogram): $145 \mathrm{~g}$ of $\mathrm{Ca}, 5 \mathrm{~g}$ of P, $85 \mathrm{~g}$ of $\mathrm{Mg}, 100 \mathrm{~g}$ of $\mathrm{Na}, 40 \mathrm{~g}$ of S, $900 \mathrm{kIU}$ of vitamin A $190 \mathrm{kIU}$ of vitamin D, 5,460 $\mathrm{mg}$ of $\alpha$-tocopherol, 4,000 $\mathrm{mg}$ of $\mathrm{Mn}, 1,500$ $\mathrm{mg}$ of $\mathrm{Cu}, 25 \mathrm{mg}$ of Co, 4,500 $\mathrm{mg}$ of Zn, $225 \mathrm{mg}$ of I, and $50 \mathrm{mg}$ of Se.

${ }^{10}$ Vitamin E premix (Suplex d-alfa E-50,000; Vitfoss) containing (per kilogram): $20 \mathrm{~g}$ of $\mathrm{Ca}, 6 \mathrm{~g}$ of $\mathrm{P}$, and 33,557 $\mathrm{mg}$ of $R R R$ - $\alpha$-tocopherol.

${ }^{11}$ Calculated from ingredient analysis using the nonadditive Nordic Feed Evaluation System (Volden, 2011).

tubing (no. 39339, 1-mm i.d., 3-mm o.d.; Ole Dich Instrumentmakers, Hvidovre, Denmark) and a peristaltic pump (model 110-B; Ole Dich Instrumentmakers). The infusate was a $175 \mathrm{~m} M$ solution of pAH (4-aminohippuric acid 99\%; Acros, Geel, Belgium) adjusted to $\mathrm{pH} 7.4$, filtered (Filter Top PES membrane $0.22 \mu \mathrm{m}$; Techno Plastic Products AG, Trasadingen, Switzerland), and autoclaved.

Feed intake and milk yield were recorded daily. Samples of prepartum and postpartum diets for DM determination were obtained biweekly and daily, respectively. The dried samples of the prepartum diet were pooled within 2 consecutive weeks, whereas postpartum diets were pooled within diet and 10 consecutive days. Milk yield was recorded using continuousflow sampling (Tru-Test HI; Tru-Test Scandinavia, Præst $\varnothing$, Denmark) and milk was sampled on sampling days at each milking from the continuous-flow sample. Feces were sampled in the morning and afternoon of sampling day +15 and +29 DIM, pooled within cow and sampling day, and stored at $-20^{\circ} \mathrm{C}$ until analysis. Cows were weighed before the afternoon feeding of each sampling day.

\section{Analytical Procedures}

Hematocrit was determined immediately in arterial samples by centrifugation in capillary tubes at 13,000 $\times g$ for 6 min at ambient temperature. Blood $\mathrm{pH}$, blood gasses, and oximetry variables were measured using an ABL700 Blood Gas Analyzer (Radiometer A/S, Copenhagen, Denmark). Plasma pAH was deacetylated before analysis (Harvey and Brothers, 1962) using a continuous-flow analyzer (Autoanalyzer 3, method US216-72 Rev. 1; Seal Analytical Ltd., Burgess Hill, UK). Before deacetylation of pAH, plasma was deproteinized by combining with an equal volume of $20 \%$ trichloroacetic acid (wt/vol) and the supernatant incubated at $100^{\circ} \mathrm{C}$ for $1 \mathrm{~h}$. Plasma concentrations of urea were determined (Marsh et al., 1965) using a continuous flow analyzer (Autoanalyzer 3, method G-373-07 Rev. 1). Urea concentration was determined in samples that had not been heat treated or deproteinized.

Heparinized plasma samples were analyzed in duplicate for AA by GC-MS using the isotope dilution method (Calder et al., 1999) in samples pooled within cow and DIM. A working AA standard was prepared from a commercial AA mixture (AAS18; Sigma-Aldrich Denmark A/S, Brøndby, Denmark) with added Gln (L-glutamine 99\%, final concentration $400 \mu \mathrm{M}$; Acros, Geel, Belgium). The internal standard was made from a $\mathrm{U}^{13} \mathrm{C} / \mathrm{U}^{15} \mathrm{~N}$ cell free AA mixture (CNLM-6696-1; Cambridge Isotope Laboratories Inc., Andover, MA). Essential AA analyzed were His, Ile, Leu, Lys, Met, Phe, Thr, Trp, and Val; and non-EAA analyzed were 
Ala, Asn, Asp, Cys, Gln, Glu, Gly, Pro, Ser, and Tyr. The method was not validated for Arg.

Heparinized plasma samples were analyzed for glucose and L-lactate using D-glucose oxidase and L-lactate oxidase, respectively (YSI 7100; YSI Inc., Yellow Springs, $\mathrm{OH}$ ), and for ammonia, glycerol, and BHBA using enzymatic assays (AM1015, GY105, and Ranbut1008, respectively; Randox Laboratories Ltd., Crumlin, UK) adapted for use on a Cobas Mira autoanalyzer (Triolab A/S, Brøndby, Denmark). Plasma content of NEFA (EDTA stabilized) was determined using an enzymatic assay (FA115; Randox Laboratories Ltd.) adapted for use on a Cobas Mira autoanalyzer. Total protein were determined using the biuret reaction end-point method (ABX Pentra Total Protein CP; Horiba ABX, Montpellier, France) adapted for use on a Cobas Mira autoanalyzer. Propionate was determined by GC-MS according to Kristensen (2000). Plasma insulin was determined by time-resolved fluoroimmunometric assay (Løvendahl and Purup, 2002). Glycerol, total protein, and insulin concentrations were determined in heparinized plasma samples pooled within cow and DIM.

Frozen pooled samples of grass-clover and corn silages were analyzed using near infrared spectroscopy at a commercial feed testing laboratory (Eurofins Steins A/S, Holstebro, Denmark). Samples of alfalfa haylage, fodder beets, mixed diets, and feces were analyzed for DM, ash, CP, NDF, and $\mathrm{Cr}_{2} \mathrm{O}_{3}$ as previously described (Larsen et al., 2009). Starch was determined using an enzymatic method (Kristensen et al., 2007). The content of reducing sugars in mixed diets and beets were determined by the reducing $\mathrm{Cu}(\mathrm{II})$ titration method (Schoorl, 1929). Milk samples were analyzed for fat, protein, and lactose (monohydrate) using a MilkoScan 4000 (Eurofins Steins A/S).

\section{Calculations and Statistical Procedures}

The ammonia concentration in whole blood was set equal to the plasma concentration, whereas the wholeblood concentration of urea was obtained by correcting for the urea dilution space in erythrocytes of $80 \%$ (Røjen et al., 2011). Whole blood concentration of propionate was obtained from plasma concentrations by correcting for a $45 \%$ dilution space in erythrocytes (Kristensen, 2000). The net PDV flux, net hepatic flux, and net splanchnic flux of metabolites were calculated as described previously (Kristensen et al., 2007). The hepatic portal recovery of glucose equivalents from feed starch was estimated by correcting the net PDV flux of glucose for a $2.4 \%$ extraction rate of arterial glucose in PDV (Larsen and Kristensen, 2009b). The ECM yield was calculated taking lactose content into account
(Sjaunja et al., 1991) using milk compositions corrected for differences in milk volume among morning, afternoon, and evening milking. The secretion of EAA in milk protein was calculated using tabulated values for content in milk (g/ $\mathrm{kg}$ of protein): His, 27; Ile, 59; Leu, 98; Lys, 83; Met, 28; Phe, 49; Thr, 43; Trp, 15; and Val, 66 (Swaisgood, 1995). The apparent total-tract digestibilities of DM, CP, starch, and NDF were calculated for 15 and 29 DIM using $\mathrm{Cr}_{2} \mathrm{O}_{3}$ as digestibility marker and average nutrient intake of the $2 \mathrm{~d}$ preceding the respective sampling days. Changes in BW at each DIM were calculated relative to prepartum BW.

Data were subjected to ANOVA using the MIXED procedure in SAS [SAS version 9.2 (TS1M0), SAS Institute Inc., Cary, NC]. The model included the fixed effect of treatment, DIM, sampling time relative to feeding, and the possible interactions. Cow was considered as a random factor and time relative to feeding within cow and sampling day as a repeated measure using the autoregressive order 1 covariance structure. For variables with 1 observation per sampling day, a reduced model was used including treatment, DIM, and the treatment $\times$ DIM interaction. Cow was considered as a random factor and DIM within cow as a repeated measure using the autoregressive order 1 covariance structure. Arterial NEFA and glycerol concentrations were $\log _{10}$ transformed to obtain normal distribution of errors.

Data are presented as least squares means \pm standard error of the mean because of missing observations: 1 portal catheter was misplaced with GLCG ( $\mathrm{n}=2$ for net portal and net hepatic fluxes), and 1 cow with ALF-GLCG had severe ketosis at 7 DIM and left the experiment $(\mathrm{n}=2$ at 15 and 29 DIM). The Fisher protected least significant difference test was used to separate treatment means within DIM. To test if treatment affected changes from prepartum to 4 DIM, data including the prepartum observations and the appropriate model described above were used for computing the Fisher least significant difference test. Significance was declared at $P \leq 0.05$ and tendencies were considered at $0.05<P \leq 0.10$.

\section{RESULTS}

The average obtained sampling days $( \pm \mathrm{SD})$ relative to parturition were $12.4 \pm 1.5 \mathrm{~d}$ prepartum, and $4.0 \pm$ $0.0,14.4 \pm 0.5$, and $28.1 \pm 0.5 \mathrm{~d}$ postpartum. One cow with the ALF-GLCG treatment had severe ketosis at 7 DIM and was removed from the experiment (Table 2 ). Two incidences of metritis occurred in connection with a twin birth and a uterine torsion. Apart from the 
Table 2. Description of cows and calves $( \pm \mathrm{SE})$ and treated illnesses

\begin{tabular}{lccc}
\hline & \multicolumn{3}{c}{ Diet $^{1}$} \\
\cline { 2 - 4 } Item & ALF-GLCG & GLCG & KETO \\
\hline BW at dry off, kg & $592 \pm 22$ & $584 \pm 42$ & $585 \pm 35$ \\
BCS at dry off & $3.1 \pm 0.2$ & $3.3 \pm 0.1$ & $3.3 \pm 0.1$ \\
Birth BW of calves, ${ }^{3} \mathrm{~kg}$ & $47 \pm 1$ & $38 \pm 4$ & $39 \pm 5$ \\
Twin births, n & $1^{4}$ & 0 & 0 \\
Postpartum illness, n & & 0 & 0 \\
Ketosis & 1 & 0 & 0 \\
Milk fever & 0 & 0 & 0 \\
Displaced abomasum & 0 & 0 & $1^{5}$ \\
Calving problems & 0 & 0 & 0 \\
Retained placenta & $1^{4}$ & 0 & $1^{5}$ \\
Metritis & $1^{4}$ & 0 & 1 \\
Mastitis & 2 & 1 & 0 \\
Leg problems & 0 & & \\
\hline
\end{tabular}

${ }^{1}$ GLCG = glucogenic diet; ALF-GLCG = diet with $100 \%$ alfalfa haylage on the day of parturition, followed by a 6 -d gradual shift to the GLCG diet; KETO = ketogenic diet.

${ }^{2}$ Scale from 1 to 5 (Ferguson et al., 1994).

${ }^{3}$ Summed BW of twins used for the twin pregnancy.

${ }^{4}$ Twin calving; the cow subsequently retained placenta and metritis.

${ }^{5}$ Uterine torsion; the cow subsequently had metritis.

ketosis incidence, the observed incidences were unproblematic with no apparent effect on performance.

\section{Feed Intake and Production Variables}

Voluntary DMI was numerically lower $(P=0.18$; Figure 1a) with ALF-GLCG from 1 to 7 DIM where alfalfa haylage was fed compared with GLCG and KETO; at +4 DIM sampling days, alfalfa haylage intake comprised $36 \pm 5 \%$ (mean $\pm \mathrm{SE}$ ) of total DMI. From 8 to 29 DIM, a tendency to interaction between treatment and DIM $(P=0.10)$ was observed for voluntary DMI, reflecting the DMI to increase with ALF-GLCG to a similar level as observed for GLCG and KETO. The apparent total-tract digestibility of starch was unaffected by treatment $(P=0.68$; Table 3$)$, whereas the total-tract digestibility of NDF was lower with KETO as compared with the other treatments $(P=0.03)$.

Milk yield did not differ $(P=0.80$; Figure $1 \mathrm{~b})$ among treatments from 1 to 7 DIM, but was greater $(P=$ $0.02)$ from 8 to 29 DIM with GLCG as compared with KETO and ALF-GLCG. Milk fat content was greater $(P=0.05$; Table 3$)$ with KETO as compared with the other treatments. Milk lactose content was greater $(P$ $<0.01)$ with GLCG as compared with the other treatments through 4 to 29 DIM. A tendency to interaction $(P=0.06)$ was observed between treatment and DIM for BW loss, reflecting that cows with GLCG had the lowest BW loss from prepartum to 4 DIM, whereas the BW loss from prepartum to 29 DIM did not differ among treatments.

\section{Arterial Variables}

Interactions were observed between treatment and DIM for the arterial concentrations of glucose, NEFA, glycerol, and BHBA $(P<0.01$ to $P=0.04$; Table 4$)$, reflecting a hyperketonemic-hypoglycemic condition with ALF-GLCG at 4 DIM, and with KETO at 15 and 29 DIM.

The arterial concentration of Lys and Met were lower $(P \leq 0.01$; Table 4$)$ with KETO as compared with the other treatments. Interactions were observed between treatment and DIM for the arterial concentrations of Ala and Gln $(P<0.01)$, reflecting the arterial glucose concentrations. The arterial concentration of Gly was

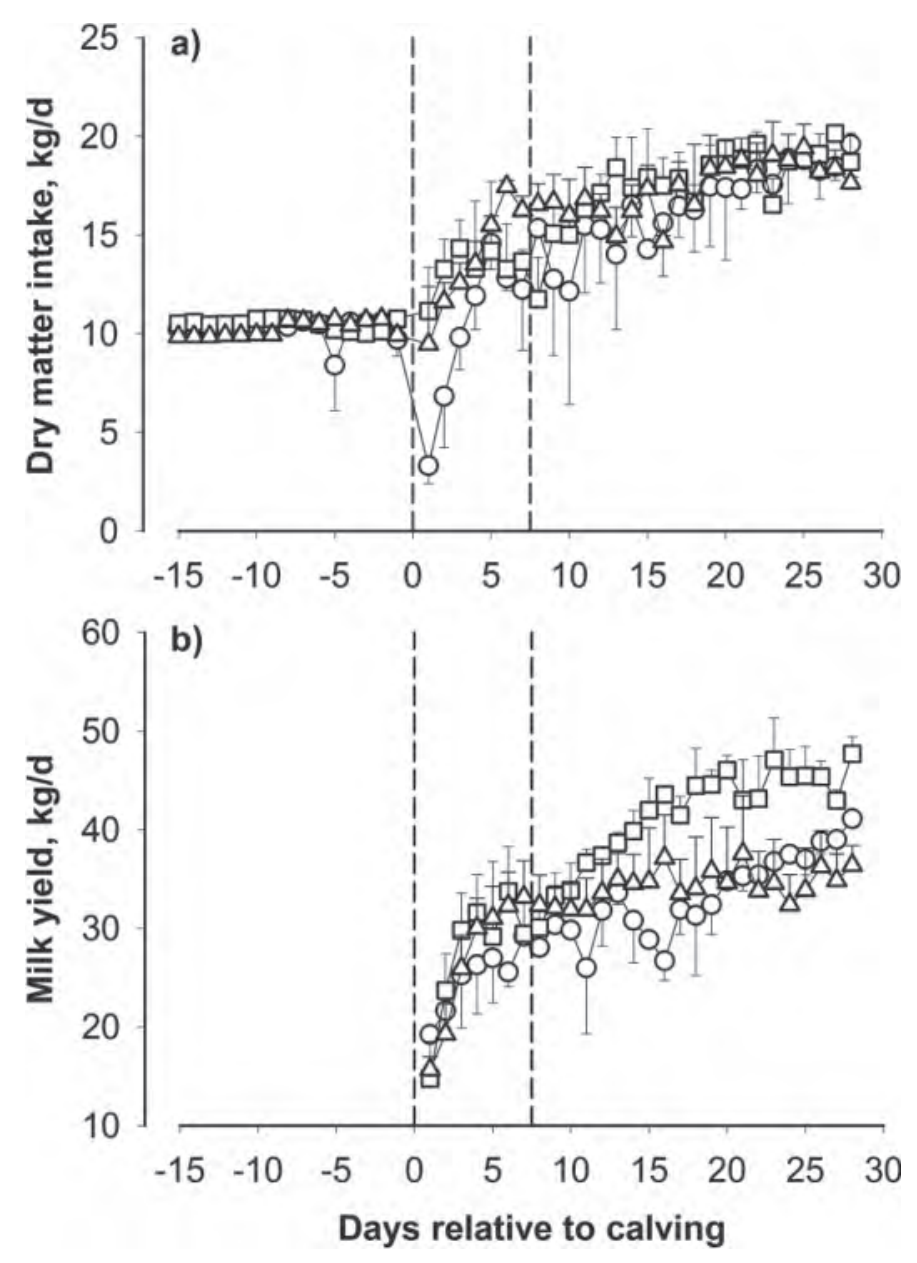

Figure 1. Total DMI (a) and milk yield (b) in dairy cows fed a glucogenic diet ( $\square$, GLCG); a ketogenic diet ( $\Delta$, KETO); or $100 \%$ alfalfa haylage on the day of parturition, followed by a 6 -d gradual shift (period between dashed lines) to the GLCG diet ( $\mathrm{O}$, ALF-GLCG). All treatments were initiated on the day of parturition. Each data point is the mean of 3 observations \pm SE. Postpartum, DMI increased at a numerically lower rate $(P=0.16)$ with ALF-GLCG compared with the other treatments. Milk yield was greater with GLCG $(P=0.04)$ compared with the other treatments. 
Table 3. Feed intake, apparent total-tract digestibility, milk production, milk composition, and cow weights ${ }^{1}$

\begin{tabular}{|c|c|c|c|c|c|c|c|c|c|c|c|c|c|c|}
\hline \multirow[b]{2}{*}{ Item } & \multirow[b]{2}{*}{ Prepartum } & \multicolumn{3}{|c|}{4 DIM } & \multicolumn{3}{|c|}{15 DIM } & \multicolumn{3}{|c|}{29 DIM } & \multirow[b]{2}{*}{$\mathrm{SEM}^{2}$} & \multicolumn{3}{|c|}{$P$-value ${ }^{3}$} \\
\hline & & $\begin{array}{c}\text { ALF- } \\
\text { GLCG }\end{array}$ & GLCG & KETO & $\begin{array}{l}\text { ALF- } \\
\text { GLCG }\end{array}$ & GLCG & KETO & $\begin{array}{l}\text { ALF- } \\
\text { GLCG }\end{array}$ & GLCG & KETO & & Trt & DIM & $\begin{array}{c}\text { Trt } \times \\
\text { DIM }\end{array}$ \\
\hline \multicolumn{15}{|c|}{ Feed intake, $\mathrm{kg} / \mathrm{d}$} \\
\hline DMI & 10.0 & 11.9 & 13.3 & 13.5 & 16.5 & 16.8 & 14.9 & 20.0 & 18.1 & 17.9 & 1.9 & 0.91 & 0.02 & 0.86 \\
\hline $\mathrm{CP}$ & 1.56 & 2.05 & 2.41 & 2.49 & 2.99 & 3.03 & 2.62 & 3.61 & 3.27 & 3.17 & 0.30 & 0.87 & 0.02 & 0.74 \\
\hline Starch & $\begin{array}{l}1.00 \\
1.79\end{array}$ & $2.87^{\mathrm{AB}, \mathrm{a}}$ & $4.91^{\mathrm{B}, \mathrm{b}}$ & $1.41^{\mathrm{A}, \mathrm{a}}$ & $6.12^{\mathrm{a}}$ & $6.19^{\mathrm{a}}$ & $1.44^{\mathrm{b}}$ & $7.37^{\mathrm{a}}$ & $6.68^{\mathrm{a}}$ & $1.75^{\mathrm{b}}$ & 0.55 & $<0.01$ & 0.01 & 0.08 \\
\hline Sugars & 0.36 & $0.56^{\mathrm{A}, \mathrm{a}}$ & $0.66^{\mathrm{A}, \mathrm{a}}$ & $3.97^{\mathrm{B}, \mathrm{b}}$ & $0.86^{\mathrm{a}}$ & $0.83^{\mathrm{a}}$ & $4.73^{\mathrm{b}}$ & $1.01^{\mathrm{a}}$ & $0.90^{\mathrm{a}}$ & $5.58^{\mathrm{b}}$ & 0.19 & $<0.01$ & $<0.01$ & $<0.01$ \\
\hline $\mathrm{NDF}$ & 3.37 & 3.14 & 2.09 & 2.17 & 2.58 & 2.63 & 2.33 & 3.14 & 2.84 & 2.80 & 0.31 & 0.22 & 0.30 & 0.69 \\
\hline \multicolumn{15}{|c|}{ Apparent total-tract digestibility, $\%$} \\
\hline DM & & & & & 77.0 & 68.1 & 72.9 & 73.0 & 73.3 & 73.5 & 2.8 & 0.46 & 0.65 & 0.39 \\
\hline $\mathrm{CP}$ & & & & & 64.6 & 59.4 & 54.0 & 63.5 & 59.6 & 60.2 & 2.5 & 0.08 & 0.43 & 0.50 \\
\hline Starch & & & & & 96.2 & 87.7 & 90.9 & 93.4 & 96.1 & 92.2 & 2.8 & 0.68 & 0.18 & 0.14 \\
\hline NDF & & & & & 65.2 & 62.1 & 46.8 & 61.3 & 58.4 & 49.7 & 5.3 & 0.03 & 0.83 & 0.85 \\
\hline \multicolumn{15}{|l|}{ Milk production } \\
\hline Milk, kg/d & & 26.3 & 31.6 & 30.0 & 30.3 & 42.5 & 35.0 & 42.7 & 46.2 & 37.1 & 3.0 & 0.23 & $<0.01$ & 0.18 \\
\hline $\mathrm{ECM}, \mathrm{kg} / \mathrm{d}$ & & 29.8 & 33.9 & 36.2 & 31.5 & 42.5 & 37.1 & 41.0 & 41.3 & 36.6 & 3.8 & 0.61 & 0.08 & 0.13 \\
\hline Fat, g/d & & 1,321 & 1,381 & 1,615 & 1,376 & 1,771 & 1,581 & 1,685 & 1,602 & 1,541 & 177 & 0.83 & 0.15 & 0.06 \\
\hline Protein, g/d & & 1,027 & 1,191 & 1,231 & 1,011 & 1,344 & 1,206 & 1,340 & 1,315 & 1,172 & 144 & 0.69 & 0.54 & 0.32 \\
\hline Lactose, g/d & & 1,122 & 1,532 & 1,362 & 1,295 & 2,044 & 1,647 & 1,929 & 2,257 & 1,697 & 135 & 0.06 & $<0.01$ & 0.23 \\
\hline \multicolumn{15}{|c|}{ Milk composition } \\
\hline Fat, $\mathrm{g} / \mathrm{kg}$ & & $4.9^{\mathrm{ab}}$ & $4.4^{\mathrm{a}}$ & $5.4^{\mathrm{b}}$ & 4.2 & 4.2 & 4.6 & $3.7^{\mathrm{ab}}$ & $3.5^{\mathrm{a}}$ & $4.2^{\mathrm{b}}$ & 0.2 & 0.05 & $<0.01$ & 0.45 \\
\hline Protein, $\mathrm{g} / \mathrm{kg}$ & & 3.8 & 3.8 & 4.1 & 3.2 & 3.2 & 3.5 & 3.2 & 2.9 & 3.2 & 0.2 & 0.56 & $<0.01$ & 0.77 \\
\hline Lactose, $\mathrm{g} / \mathrm{kg}$ & & $4.3^{\mathrm{a}}$ & $4.8^{\mathrm{b}}$ & $4.5^{\mathrm{c}}$ & $4.5^{\mathrm{a}}$ & $4.8^{\mathrm{b}}$ & $4.7^{\mathrm{b}}$ & $4.6^{\mathrm{a}}$ & $4.9^{\mathrm{b}}$ & $4.6^{\mathrm{a}}$ & 0.1 & $<0.01$ & 0.08 & 0.15 \\
\hline $\mathrm{BW}, \mathrm{kg}$ & 665 & $604^{\mathrm{A}}$ & $617^{\mathrm{B}}$ & $626^{\mathrm{A}}$ & 580 & 576 & 612 & 580 & 552 & 587 & 27 & 0.65 & $<0.01$ & 0.05 \\
\hline BW loss, $\mathrm{kg}$ & & $78^{\mathrm{a}}$ & $15^{\mathrm{b}}$ & $54^{\mathrm{ab}}$ & 105 & 56 & 68 & 107 & 80 & 93 & 13 & 0.17 & $<0.01$ & 0.06 \\
\hline
\end{tabular}

${ }^{\mathrm{A}, \mathrm{B}}$ Signify the Fisher least significant difference test for treatment to affect prepartum to 4 DIM changes $(P \leq 0.05)$.

D $\quad{ }^{\mathrm{a}-\mathrm{c}}$ Within a row and within DIM, LSM with different superscript lowercase letters are significantly different $(P \leq 0.05)$.

을 ${ }^{1}$ Treatments (Trt) were initiated at parturition and were a glucogenic diet (GLCG); a ketogenic diet (KETO); or a linear shift from $100 \%$ alfalfa haylage at 1 DIM to $100 \%$ GLCG D. 7 DIM (ALF-GLCG).

( $)$ Standard error of the mean $(\mathrm{n}=3)$.

กำ. ${ }^{3}$ Fixed effects for postpartum observations (treatments initiated at parturition). 


\begin{tabular}{|c|c|c|c|c|c|c|c|c|c|c|c|c|c|c|}
\hline \multirow[b]{2}{*}{ Item } & \multirow[b]{2}{*}{ Prepartum } & \multicolumn{3}{|c|}{4 DIM } & \multicolumn{3}{|c|}{15 DIM } & \multicolumn{3}{|c|}{$29 \mathrm{DIM}$} & \multirow[b]{2}{*}{$\mathrm{SEM}^{2}$} & \multicolumn{3}{|c|}{$P$-value ${ }^{3}$} \\
\hline & & $\begin{array}{l}\text { ALF- } \\
\text { GLCG }\end{array}$ & GLCG & KETO & $\begin{array}{l}\text { ALF- } \\
\text { GLCG }\end{array}$ & GLCG & KETO & $\begin{array}{l}\text { ALF- } \\
\text { GLCG }\end{array}$ & GLCG & KETO & & Trt & DIM & $\begin{array}{c}\text { Trt } \times \\
\text { DIM }\end{array}$ \\
\hline \multicolumn{15}{|l|}{ Blood plasma } \\
\hline Glucose, $\mathrm{m} M$ & 3.86 & $2.85^{\mathrm{a}}$ & $3.44^{\mathrm{b}}$ & $3.32^{\mathrm{ab}}$ & $3.13^{\mathrm{a}}$ & $3.13^{\mathrm{a}}$ & $2.27^{\mathrm{b}}$ & $3.52^{\mathrm{a}}$ & $3.40^{\mathrm{a}}$ & $2.31^{\mathrm{b}}$ & 0.16 & 0.04 & 0.03 & $<0.01$ \\
\hline L-Lactate, $\mathrm{m} M$ & 0.47 & $0.44^{\mathrm{AB}}$ & $0.37^{\mathrm{A}}$ & $0.48^{\mathrm{B}}$ & 0.26 & 0.29 & 0.19 & 0.27 & 0.25 & 0.23 & 0.05 & 0.82 & $<0.01$ & 0.07 \\
\hline Insulin, $\mathrm{p} M$ & 93 & $11^{\mathrm{A}}$ & $31^{\mathrm{AB}}$ & $44^{\mathrm{B}}$ & 18 & 40 & 39 & 50 & 47 & 49 & 14 & 0.35 & 0.18 & 0.66 \\
\hline NEFA & 115 & 713 & 338 & 470 & 449 & 307 & 394 & 169 & 208 & 302 & 101 & $0.57^{4}$ & $<0.01$ & 0.01 \\
\hline Glycerol & 16 & 54 & 32 & 30 & 29 & 20 & 22 & 9 & 13 & 18 & 6 & $0.88^{4}$ & $<0.01$ & 0.04 \\
\hline BHBA & 662 & 1,071 & 786 & 1,005 & $987^{\mathrm{a}}$ & $1,055^{\mathrm{a}}$ & $2,479^{\mathrm{b}}$ & $784^{\mathrm{a}}$ & $655^{\mathrm{a}}$ & $4,322^{\mathrm{b}}$ & 276 & $<0.01$ & 0.01 & $<0.01$ \\
\hline Total protein, & & & & & & & & & & & & & & \\
\hline $\mathrm{g} / \mathrm{L}$ & 80 & $77^{\mathrm{A}}$ & $74^{\mathrm{B}}$ & $81^{\mathrm{A}}$ & 76 & 85 & 85 & 80 & 87 & 90 & 3 & 0.36 & 0.02 & 0.36 \\
\hline $\mathrm{EAA}^{5}$ & 659 & 660 & 665 & 645 & 619 & 814 & 714 & 741 & 729 & 869 & 55 & 0.36 & 0.06 & 0.25 \\
\hline His & 44 & 52 & 48 & 48 & $44^{\mathrm{a}}$ & $43^{\mathrm{a}}$ & $30^{\mathrm{b}}$ & $57^{\mathrm{a}}$ & $48^{\mathrm{a}}$ & $37^{\mathrm{b}}$ & 3 & 0.06 & $<0.01$ & 0.16 \\
\hline Ile & 105 & 98 & 90 & 78 & 79 & 117 & 104 & 80 & 84 & 121 & 11 & 0.49 & 0.45 & 0.09 \\
\hline Leu & 102 & 122 & 148 & 134 & 139 & 199 & 190 & $146^{\mathrm{a}}$ & $151^{\mathrm{a}}$ & $233^{\mathrm{b}}$ & 18 & 0.04 & 0.04 & 0.15 \\
\hline Lys & 70 & $64^{\mathrm{A}, \mathrm{a}}$ & $47^{\mathrm{B}, \mathrm{b}}$ & $42^{\mathrm{AB}, \mathrm{b}}$ & $55^{\mathrm{a}}$ & $55^{\mathrm{a}}$ & $40^{\mathrm{b}}$ & 51 & 57 & 47 & 5 & $<0.01$ & 0.75 & 0.08 \\
\hline Met & 22 & 20 & 19 & 18 & 15 & 15 & 11 & $19^{\mathrm{a}}$ & $17^{\mathrm{a}}$ & $13^{\mathrm{b}}$ & 1 & 0.01 & $<0.01$ & 0.46 \\
\hline Phe & 45 & 50 & 47 & 45 & $48^{\mathrm{a}}$ & $52^{\mathrm{a}}$ & $60^{\mathrm{b}}$ & $47^{\mathrm{a}}$ & $51^{\mathrm{a}}$ & $64^{\mathrm{b}}$ & 3 & 0.03 & 0.01 & 0.02 \\
\hline Thr & 83 & $62^{\mathrm{AB}, \mathrm{a}}$ & $67^{\mathrm{A}, \mathrm{ab}}$ & $84^{\text {B.b }}$ & 65 & 68 & 52 & $113^{\mathrm{a}}$ & $98^{\mathrm{a}}$ & $73^{\mathrm{b}}$ & 8 & 0.46 & $<0.01$ & 0.02 \\
\hline Trp & 28 & 23 & 26 & 23 & 32 & 35 & 29 & 40 & 41 & 34 & 3 & 0.29 & $<0.01$ & 0.91 \\
\hline Val & 179 & 170 & 174 & 173 & 152 & 231 & 197 & 183 & 181 & 247 & 21 & 0.21 & 0.23 & 0.20 \\
\hline Non-EAA & 1,159 & $948^{\mathrm{A}, \mathrm{a}}$ & $1,463^{\mathrm{B}, \mathrm{b}}$ & $1,464^{\mathrm{B}, \mathrm{b}}$ & 1,342 & 1,418 & 1,274 & 1,469 & 1,414 & 1,432 & 85 & 0.16 & 0.17 & 0.01 \\
\hline Ala & 165 & $125^{\mathrm{A}, \mathrm{a}}$ & $160^{\mathrm{AB}, \mathrm{b}}$ & $143^{\mathrm{B}, \mathrm{ab}}$ & $138^{\mathrm{a}}$ & $185^{\mathrm{b}}$ & $98^{\mathrm{c}}$ & $206^{\mathrm{a}}$ & $198^{\mathrm{a}}$ & $104^{\mathrm{b}}$ & 11 & $<0.01$ & 0.01 & $<0.01$ \\
\hline Asn & 44 & $35^{\mathrm{A}}$ & $75^{\mathrm{B}}$ & $46^{\mathrm{B}}$ & 65 & 63 & 42 & 71 & 77 & 44 & 10 & 0.10 & 0.33 & 0.11 \\
\hline Asp & 4 & $2^{\mathrm{a}}$ & $4^{\mathrm{b}}$ & $2^{\mathrm{a}}$ & $2^{\mathrm{ab}}$ & $4^{\mathrm{a}}$ & $2^{\mathrm{b}}$ & $3^{\mathrm{ab}}$ & $4^{\mathrm{a}}$ & $2^{\mathrm{b}}$ & 1 & 0.03 & 0.03 & 0.34 \\
\hline Cys & 112 & $101^{\mathrm{A}, \mathrm{a}}$ & $61^{\mathrm{B}, \mathrm{b}}$ & $69^{\mathrm{B}, \mathrm{b}}$ & 78 & 77 & 82 & 81 & 82 & 78 & 6 & 0.31 & 0.53 & $<0.01$ \\
\hline Gln & 330 & $160^{\mathrm{A}, \mathrm{a}}$ & $376^{\mathrm{B}, \mathrm{b}}$ & $276^{\mathrm{C}, \mathrm{ab}}$ & 243 & 288 & 153 & 245 & 284 & 195 & 53 & 0.22 & 0.03 & $<0.01$ \\
\hline Glu & 71 & $33^{\mathrm{A}, \mathrm{a}}$ & $44^{\mathrm{B}, \mathrm{b}}$ & $37^{\mathrm{AB}, \mathrm{b}}$ & 44 & 41 & 41 & $46^{\mathrm{a}}$ & $38^{\mathrm{b}}$ & $39^{\mathrm{ab}}$ & 3 & 0.70 & 0.12 & 0.01 \\
\hline Gly & 246 & $325^{\mathrm{A}, \mathrm{a}}$ & $469^{\mathrm{B}, \mathrm{b}}$ & $591^{\mathrm{B}, \mathrm{b}}$ & $502^{\mathrm{a}}$ & $485^{\mathrm{a}}$ & $648^{\mathrm{b}}$ & $438^{\mathrm{a}}$ & $418^{\mathrm{a}}$ & $713^{\mathrm{b}}$ & 38 & 0.01 & 0.03 & 0.04 \\
\hline Pro & 60 & $61^{\mathrm{a}}$ & $91^{\mathrm{b}}$ & $96^{\mathrm{b}}$ & 101 & 102 & 85 & 141 & 110 & 119 & 8 & 0.88 & $<0.01$ & 0.03 \\
\hline Ser & 77 & $77^{\mathrm{A}, \mathrm{a}}$ & $128^{\mathrm{AB}, \mathrm{b}}$ & $163^{\mathrm{B}, \mathrm{b}}$ & $140^{\mathrm{a}}$ & $118^{\mathrm{ab}}$ & $85^{\mathrm{b}}$ & $179^{\mathrm{a}}$ & $136^{\mathrm{ab}}$ & $91^{\mathrm{b}}$ & 14 & 0.60 & 0.39 & $<0.01$ \\
\hline Tyr & 44 & $29^{\mathrm{a}}$ & $52^{\mathrm{b}}$ & $41^{\mathrm{ab}}$ & $46^{\mathrm{ab}}$ & $55^{\mathrm{a}}$ & $39^{\mathrm{b}}$ & $70^{\mathrm{a}}$ & $66^{\mathrm{a}}$ & $47^{\mathrm{b}}$ & 5 & 0.04 & $<0.01$ & 0.11 \\
\hline Total AA & 1,818 & $1,608^{\mathrm{A}, \mathrm{a}}$ & $2,128^{\mathrm{B}, \mathrm{b}}$ & $2,109^{\mathrm{B}, \mathrm{b}}$ & 2,005 & 2,232 & 1,987 & 2,224 & 2,143 & 2,301 & 101 & 0.03 & 0.03 & 0.05 \\
\hline \multicolumn{15}{|l|}{ Whole blood } \\
\hline Hematocrit, \% & 29.7 & $34.1^{\mathrm{A}, \mathrm{a}}$ & $33.2^{\mathrm{AB}, \mathrm{ab}}$ & $31.4^{\mathrm{B}, \mathrm{b}}$ & 29.1 & 28.8 & 27.7 & 26.2 & 26.8 & 25.4 & 0.6 & 0.16 & $<0.01$ & 0.03 \\
\hline $\mathrm{pH}$ & 7.44 & 7.48 & 7.46 & 7.47 & 7.45 & 7.44 & 7.45 & 7.43 & 7.44 & 7.44 & 0.01 & 0.58 & $<0.01$ & 0.59 \\
\hline $\mathrm{O}_{2}, \mathrm{~m} M$ & 6.2 & $6.9^{\mathrm{A}, \mathrm{a}}$ & $6.7^{\mathrm{B}, \mathrm{a}}$ & $6.3^{\mathrm{B}, \mathrm{b}}$ & 5.8 & 5.9 & 5.7 & 5.3 & 5.5 & 5.2 & 0.1 & 0.18 & $<0.01$ & $<0.01$ \\
\hline $\mathrm{CO}_{2}, \mathrm{~m} M$ & 24.8 & 29.7 & 29.0 & 30.7 & 27.0 & 26.8 & 26.6 & 27.5 & 27.7 & 26.2 & 1.1 & 0.93 & 0.01 & 0.47 \\
\hline Propionate & 28 & 56 & 46 & 50 & 46 & 52 & 46 & 59 & 56 & 39 & 9 & 0.59 & 0.97 & 0.81 \\
\hline Ammonia & 154 & 150 & 158 & 156 & 131 & 148 & 147 & 130 & 166 & 166 & 11 & 0.41 & 0.04 & 0.26 \\
\hline Urea, $\mathrm{m} M$ & 2.89 & 4.39 & 3.53 & 3.83 & 3.28 & 2.88 & 2.61 & 3.10 & 3.26 & 3.30 & 0.46 & 0.73 & 0.05 & 0.76 \\
\hline
\end{tabular}

${ }^{\mathrm{A}-\mathrm{C}}$ Signify the Fisher least significant difference test for treatment to affect prepartum to 4 DIM changes $(P \leq 0.05)$.

${ }^{\mathrm{a}-\mathrm{c}}$ Within a row and within DIM, LSM with different superscript lowercase letters are significantly different $(P \leq 0.05)$.

${ }^{1}$ Treatments (Trt) were initiated at parturition and were a glucogenic diet (GLCG), a ketogenic diet (KETO), or a linear shift from $100 \%$ alfalfa haylage at 1 DIM to $100 \%$ GLCG at 7 DIM (ALF-GLCG).

${ }^{2}$ Standard error of the mean $(\mathrm{n}=3)$

${ }^{3}$ Fixed effects for postpartum observations (treatments initiated at parturition).

${ }^{4} P$-values are for the $\log _{10}$-transformed variable.

${ }^{5} \mathrm{EAA}=$ essential AA. 
greater and increasing with DIM for KETO compared with lower and relatively stable Gly concentrations for the other treatments (interaction: $P=0.04$ ).

\section{Net Portal Fluxes}

An interaction existed between treatment and DIM $(P<0.01$; Table 5$)$ for the net portal flux of glucose, reflecting the higher intake of ruminal escape starch with GLCG compared with a lower intake with KETO, and the postponed shift to the GLCG diet with ALFGLCG. The recovery of feed starch in portal blood plasma as glucose was $10 \pm 2 \%$ (mean $\pm \mathrm{SE}$ ) with the prepartum diet. Postpartum, the portal recovery of feed starch was $28 \pm 3 \%$ with KETO, which was greater $(P$ $=0.02$ ) compared with $10 \pm 3 \%$ for ALF-GLCG and $15 \pm 4 \%$ with GLCG.

The net portal fluxes of Ile, Leu, Lys, Phe, Thr, and Trp were greater with GLCG $(P<0.01$ to $P=0.02)$ compared with the other treatments. The net portal fluxes of all AA, apart from Trp, Asp, and Gln, increased with increasing DIM $(P<0.01$ to $P=0.07)$.

\section{Net Hepatic Fluxes}

The net hepatic release of glucose was greatest with KETO and least with ALF-GLCG at 4 DIM, after which it increased as lactation progressed with both ALF-GLCG and GLCG but not with KETO (interaction: $P=0.02$; Table 6 ). The net hepatic removal of lactate and glycerol increased from prepartum to 4 DIM with all treatments $(P<0.01$; not shown $)$, after which it decreased as lactation progressed $(P<0.01)$.

Negative net hepatic fluxes (net removal) of all individual EAA were observed both prepartum and at 4 DIM (Table 6). The net hepatic removal of Ile, Leu, and Val at 4 DIM had generally changed to a numerical net hepatic release by $29 \mathrm{DIM}(P=0.01$ to 0.18$)$. Apart from Met, the net hepatic fluxes of EAA were not affected by postpartum treatments $(P=0.10$ to 0.90$)$. The net hepatic removal of Met increased more $(P=$ 0.04) from prepartum to 4 DIM with ALF-GLCG compared with GLCG. At 15 and 29 DIM, the net hepatic removal of Met had become similar among treatments (interaction: $P=0.07$ ). The net hepatic removal of Ala, Gly, and Ser increased from prepartum to 4 DIM with all treatments $(P<0.01$; not shown $)$. Postpartum, the net hepatic removal of Gly was higher with KETO $(P$ $=0.03$ ) compared with the other treatments.

The hepatic removal of lactate as percent of PDV release and of total influx increased from prepartum to 4 DIM (Figure 2; $P<0.01$ ). The hepatic removal of lactate as percent of PDV release was less with GLCG at 4 DIM compared with the other treatments at 4
DIM, but did not differ at 15 and 29 DIM (interaction, $P=0.02$ ). The hepatic removal of lactate as percent of total influx was unaffected by postpartum treatments $(P=0.78)$, but decreased as lactation progressed $(P<$ $0.01)$.

\section{Net Splanchnic Fluxes}

The net splanchnic release of glucose was least with ALF-GLCG at 4 DIM, after which it increased until 29 DIM, reaching a similar level to that of GLCG. In contrast, the net splanchnic glucose release did not increase as lactation progressed with KETO (interaction: $P<0.01$; Table 7).

Apart from His, Lys, and Met, net splanchnic releases of EAA were generally unaffected by treatment $(P=0.16$ to 0.49 ; Table 7$)$. The net splanchnic flux of His and Met decreased from prepartum to 4 DIM with ALF-GLCG, which differed $(P \leq 0.05)$ from increasing fluxes from prepartum to 4 DIM with GLCG. At 15 and 29 DIM, the net splanchnic releases of His and Met had become similar among treatments (interactions: $P$ $=0.04$ and 0.07, respectively). Apart from Trp, net splanchnic releases of EAA increased as lactation progressed $(P<0.01$ to $P=0.02)$. The balance between net splanchnic release and estimated milk secretion of EAA was $-260 \pm 40 \mathrm{~g} / \mathrm{d}$ at 4 DIM increasing $(P<$ $0.01)$ to $7 \pm 43 \mathrm{~g} / \mathrm{d}$ at $29 \mathrm{DIM}$, and was unaffected by treatment $(P=0.60)$.

\section{DISCUSSION}

\section{Splanchnic Glucose Metabolism}

One objective of the present experiment was to investigate the possibility of increasing the glucogenic status of postpartum transition cows with diets applicable under field conditions. The rationale behind was to exploit that glucose infused into the abomasum recently was shown to be efficiently transferred to peripheral tissues in postpartum transition cows, leading to an overall increased glucogenic status and decreased NEFA levels (Larsen and Kristensen, 2009b). Wheat grain treated with $\mathrm{NaOH}$ was chosen as the glucogenic feedstuff, as it seems to posses the warranted combination of low ruminal degradability and high small intestinal digestibility of starch without major increases in fecal starch loss (Phipps et al., 2001; Larsen et al., 2009). The portal recovery of feed starch as glucose absorbed to portal blood in the prepartum diet $(10 \pm 2 \%$, mean $\pm \mathrm{SE}$ ) was consistent with the extent of ruminal escape starch reported for corn silage and barley grain of Danish origin (Jensen et al., 2005; Larsen et al., 2009). It was interesting to note that the portal recovery of feed 


\begin{tabular}{|c|c|c|c|c|c|c|c|c|c|c|c|c|c|c|}
\hline \multirow[b]{2}{*}{ Item } & \multirow[b]{2}{*}{ Prepartum } & \multicolumn{3}{|c|}{$4 \mathrm{DIM}$} & \multicolumn{3}{|c|}{15 DIM } & \multicolumn{3}{|c|}{29 DIM } & \multirow[b]{2}{*}{$\mathrm{SEM}^{2}$} & \multicolumn{3}{|c|}{$P$-value ${ }^{3}$} \\
\hline & & $\begin{array}{l}\text { ALF- } \\
\text { GLCG }\end{array}$ & GLCG & KETO & $\begin{array}{l}\text { ALF- } \\
\text { GLCG }\end{array}$ & GLCG & KETO & $\begin{array}{l}\text { ALF- } \\
\text { GLCG }\end{array}$ & GLCG & KETO & & Trt & DIM & $\begin{array}{c}\text { Trt } \times \\
\text { DIM }\end{array}$ \\
\hline \multicolumn{15}{|l|}{ Plasma flow } \\
\hline Portal venous & 759 & $778^{\mathrm{A}, \mathrm{a}}$ & $1,046^{\mathrm{B}, \mathrm{b}}$ & $1,113^{\mathrm{B}, \mathrm{b}}$ & $1,042^{\mathrm{a}}$ & $1,314^{\mathrm{ab}}$ & $1,556^{\mathrm{b}}$ & $1,278^{\mathrm{a}}$ & $1,265^{\mathrm{a}}$ & $1,660^{\mathrm{b}}$ & 74 & 0.03 & $<0.01$ & 0.01 \\
\hline Hepatic venous & 800 & $873^{\mathrm{A}, \mathrm{a}}$ & $1,144^{\mathrm{B}, \mathrm{ab}}$ & $1,186^{\mathrm{B}, \mathrm{b}}$ & $1,169^{\mathrm{a}}$ & $1,346^{\mathrm{a}}$ & $1,650^{\mathrm{b}}$ & $1,377^{\mathrm{a}}$ & $1,348^{\mathrm{a}}$ & $1,831^{\mathrm{b}}$ & 89 & 0.04 & $<0.01$ & $<0.01$ \\
\hline Hepatic arterial & 48 & 100 & 115 & 73 & 137 & 62 & 116 & 108 & 160 & 171 & 54 & 0.98 & 0.28 & 0.50 \\
\hline \multicolumn{15}{|l|}{ PDV plasma flux } \\
\hline Glucose & -23 & $29^{\mathrm{ab}}$ & $70^{\mathrm{a}}$ & $23^{\mathrm{b}}$ & $41^{\mathrm{a}}$ & $118^{\mathrm{b}}$ & $-2^{\mathrm{a}}$ & $113^{\mathrm{a}}$ & $110^{\mathrm{a}}$ & $37^{\mathrm{b}}$ & 14 & 0.01 & $<0.01$ & $<0.01$ \\
\hline \multicolumn{15}{|l|}{ Corrected } \\
\hline $\begin{array}{l}\text { glucose } \\
\text { L-Lactate }\end{array}$ & $\begin{array}{l}49 \\
93\end{array}$ & $\begin{array}{r}83 \\
104\end{array}$ & $\begin{array}{l}155 \\
132\end{array}$ & $\begin{array}{l}113 \\
106\end{array}$ & $\begin{array}{l}120^{\circ} \\
122\end{array}$ & $\begin{array}{l}220^{\circ} \\
132\end{array}$ & $83^{\mathrm{a}}$ & $\begin{array}{l}220^{a} \\
137\end{array}$ & $\begin{array}{l}212^{\mathrm{a}} \\
169\end{array}$ & $\begin{array}{l}130^{\circ} \\
173\end{array}$ & $\begin{array}{l}18 \\
14\end{array}$ & 0.03 & $\begin{array}{l}<0.01 \\
<0.01\end{array}$ & $\begin{array}{r}<0.01 \\
0.11\end{array}$ \\
\hline Glycerol & 2.7 & 11.8 & 15.5 & 22.0 & 6.6 & 7.8 & 11.1 & -0.9 & 0.4 & 3.3 & 4.9 & 0.57 & $<0.01$ & 0.92 \\
\hline $\mathrm{EAA}^{4}$ & 60 & $97^{\mathrm{a}}$ & $188^{\mathrm{b}}$ & $146^{\mathrm{ab}}$ & 165 & 213 & 157 & 236 & 291 & 209 & 24 & $<0.01$ & $<0.01$ & 0.40 \\
\hline His & 2.7 & 2.9 & 9.8 & 8.5 & 8.1 & 7.3 & 4.9 & 13.6 & 15.3 & 13.1 & 3.0 & 0.47 & 0.03 & 0.64 \\
\hline Ile & 10 & $12^{\mathrm{a}}$ & $28^{\mathrm{b}}$ & $19^{\mathrm{ab}}$ & 23 & 26 & 18 & 32 & 40 & 29 & 4 & $<0.01$ & $<0.01$ & 0.41 \\
\hline Leu & 12 & $22^{\mathrm{a}}$ & $46^{\mathrm{b}}$ & $34^{\mathrm{ab}}$ & 40 & 52 & 35 & 55 & 65 & 52 & 5 & $<0.01$ & $<0.01$ & 0.59 \\
\hline Lys & 14 & $14^{\mathrm{a}}$ & $26^{\mathrm{b}}$ & $20^{\mathrm{ab}}$ & $21^{\mathrm{a}}$ & $35^{\mathrm{b}}$ & $24^{\mathrm{a}}$ & $32^{\mathrm{ab}}$ & $41^{\mathrm{a}}$ & $28^{\mathrm{b}}$ & 3 & $<0.01$ & $<0.01$ & 0.38 \\
\hline Met & 3.7 & 5.9 & 9.2 & 7.0 & 8.9 & 11.1 & 9.1 & 11.7 & 13.8 & 10.4 & 0.8 & 0.14 & $<0.01$ & 0.47 \\
\hline Phe & 7 & $11^{\mathrm{a}}$ & $22^{\mathrm{b}}$ & $18^{\mathrm{ab}}$ & 21 & 24 & 21 & $27^{\mathrm{ab}}$ & $33^{\mathrm{a}}$ & $25^{\mathrm{b}}$ & 2 & $<0.01$ & $<0.01$ & 0.34 \\
\hline Thr & 7 & 11 & 20 & 16 & 17 & 20 & 19 & 24 & 31 & 25 & 3 & 0.02 & $<0.01$ & 0.82 \\
\hline Trp & 1.4 & 2.2 & 3.7 & 2.2 & 3.3 & 3.8 & 1.5 & $3.4^{\mathrm{a}}$ & $5.2^{\mathrm{a}}$ & $1.1^{\mathrm{b}}$ & 0.7 & $<0.01$ & 0.72 & 0.27 \\
\hline Val & 9 & 15 & 25 & 22 & 28 & 34 & 23 & 36 & 47 & 25 & 5 & 0.15 & 0.02 & 0.35 \\
\hline Non-EAA & 42 & 134 & 167 & 176 & 209 & 253 & 216 & 281 & 359 & 300 & 34 & 0.42 & $<0.01$ & 0.80 \\
\hline Ala & 23 & 31 & 54 & 49 & 63 & 72 & 65 & 77 & 83 & 75 & 8 & 0.11 & $<0.01$ & 0.69 \\
\hline Asn & 7 & 23 & 29 & 30 & 32 & 20 & 28 & 20 & 19 & 29 & 6 & 0.36 & 0.64 & 0.50 \\
\hline Asp & 0.6 & $0.7^{\mathrm{A}}$ & $1.6^{\mathrm{AB}}$ & $2.3^{\mathrm{B}}$ & 1.1 & 2.0 & 2.1 & 1.9 & 2.3 & 1.9 & 0.5 & 0.35 & 0.25 & 0.21 \\
\hline Cys & 0.8 & 3.0 & 4.6 & 2.0 & $3.1^{\mathrm{a}}$ & $5.1^{\mathrm{a}}$ & $-4.0^{\mathrm{b}}$ & 6.1 & 7.6 & 3.1 & 2.0 & $<0.01$ & 0.03 & 0.40 \\
\hline Gln & -16 & 17 & -15 & 4 & 10 & 29 & 39 & 36 & 80 & 56 & 35 & 0.94 & 0.22 & 0.85 \\
\hline Glu & -2.8 & 1.4 & 2.0 & 4.6 & 2.0 & 8.9 & 2.7 & 7.7 & 9.3 & 4.8 & 1.9 & 0.18 & 0.07 & 0.21 \\
\hline Gly & 13 & 19 & 18 & 22 & 28 & 28 & 15 & 43 & 52 & 52 & 6 & 0.87 & $<0.01$ & 0.27 \\
\hline Pro & 5 & $10^{\mathrm{a}}$ & $19^{\mathrm{b}}$ & $17^{\mathrm{b}}$ & 19 & 27 & 20 & $23^{\mathrm{ab}}$ & $31^{\mathrm{a}}$ & $23^{\mathrm{b}}$ & 2 & $<0.01$ & $<0.01$ & 0.52 \\
\hline Ser & 14 & $19^{\mathrm{a}}$ & $37^{\mathrm{b}}$ & $31^{\mathrm{b}}$ & 29 & 41 & 33 & 41 & 47 & 37 & 4 & 0.05 & 0.02 & 0.41 \\
\hline Tyr & 6 & $10^{\mathrm{a}}$ & $19^{\mathrm{b}}$ & $14^{\mathrm{ab}}$ & 16 & 20 & 16 & $22^{\mathrm{ab}}$ & $27^{\mathrm{a}}$ & $19^{\mathrm{b}}$ & 2 & $<0.01$ & $<0.01$ & 0.28 \\
\hline \multirow{2}{*}{\multicolumn{15}{|c|}{ PDV blood flux }} \\
\hline & & & & & & & & & & & & & & \\
\hline $\mathrm{O}_{2}$ & $-1,615$ & $-1,520^{\mathrm{a}}$ & $-2,001^{\mathrm{b}}$ & $-1,752^{\mathrm{ab}}$ & $-1,833^{\mathrm{a}}$ & $-2,329^{\mathrm{ab}}$ & $-2,467^{\mathrm{b}}$ & $-2,422$ & $-2,297$ & $-2,597$ & 134 & 0.30 & $<0.01$ & $<0.01$ \\
\hline $\mathrm{CO}_{2}$ & 1,956 & 1,728 & 2,140 & 2,045 & $1,953^{\mathrm{a}}$ & $3,080^{\mathrm{b}}$ & $3,113^{\mathrm{b}}$ & $2,892^{\mathrm{ab}}$ & $2,550^{\mathrm{a}}$ & $3,732^{\mathrm{b}}$ & 322 & 0.12 & $<0.01$ & 0.05 \\
\hline Propionate & 471 & 488 & 527 & 648 & 616 & 759 & 576 & 866 & 820 & 632 & 93 & 0.57 & 0.07 & 0.24 \\
\hline Ammonia & 279 & 257 & 242 & 313 & 208 & 268 & 273 & 293 & 325 & 346 & 37 & 0.43 & 0.03 & 0.80 \\
\hline Urea & -89 & $-111^{\mathrm{A}, \mathrm{a}}$ & $-111^{\mathrm{A}, \mathrm{a}}$ & $-205^{\mathrm{B}, \mathrm{b}}$ & $-98^{\mathrm{a}}$ & $-170^{\mathrm{b}}$ & $-179^{\mathrm{b}}$ & -165 & -189 & -212 & 21 & $<0.01$ & 0.07 & 0.27 \\
\hline
\end{tabular}

${ }^{\mathrm{A}, \mathrm{B}}$ Signify the Fisher least significant difference test for treatment to affect prepartum to 4 DIM changes $(P \leq 0.05)$.

${ }^{\mathrm{a}, \mathrm{b}}$ Within a row and within DIM, LSM with different superscript lowercase letters are significantly different $(P \leq 0.05)$.

${ }^{1}$ Treatments (Trt) were initiated at parturition and were a glucogenic diet (GLCG), a ketogenic diet (KETO), or a linear shift from 100\% alfalfa haylage at 1 DIM to $100 \%$ GLCG at 7 DIM (ALF-GLCG)

${ }^{2}$ Standard error of the mean $(\mathrm{n}=2)$

${ }^{3}$ Fixed effects for postpartum observations (treatments initiated at parturition).

${ }^{4} \mathrm{EAA}=$ essential AA. 
Table 6. Net hepatic metabolite fluxes $(\mathrm{mmol} / \mathrm{h})^{1}$

\begin{tabular}{|c|c|c|c|c|c|c|c|c|c|c|c|c|c|c|}
\hline \multirow[b]{2}{*}{ Item } & \multirow[b]{2}{*}{ Prepartum } & \multicolumn{3}{|c|}{4 DIM } & \multicolumn{3}{|c|}{15 DIM } & \multicolumn{3}{|c|}{29 DIM } & \multirow[b]{2}{*}{$\mathrm{SEM}^{2}$} & \multicolumn{3}{|c|}{$P$-value ${ }^{3}$} \\
\hline & & $\begin{array}{l}\text { ALF- } \\
\text { GLCG }\end{array}$ & GLCG & KETO & $\begin{array}{l}\text { ALF- } \\
\text { GLCG }\end{array}$ & GLCG & KETO & $\begin{array}{l}\text { ALF- } \\
\text { GLCG }\end{array}$ & GLCG & KETO & & Trt & DIM & $\begin{array}{l}\text { Trt } \times \\
\text { DIM }\end{array}$ \\
\hline \multicolumn{15}{|l|}{ Plasma flux } \\
\hline Glucose & 319 & $433^{\mathrm{a}}$ & $530^{\mathrm{ab}}$ & $602^{\mathrm{b}}$ & 538 & 567 & 525 & 680 & 673 & 599 & 52 & 0.87 & $<0.01$ & 0.02 \\
\hline L-Lactate & -121 & -288 & -306 & -351 & -203 & -252 & -231 & -166 & -201 & -246 & 27 & 0.42 & $<0.01$ & 0.33 \\
\hline Glycerol & -11 & -48 & -48 & -50 & -31 & -31 & -38 & -10 & -16 & -28 & 9 & 0.75 & $<0.01$ & 0.89 \\
\hline $\mathrm{EAA}^{4}$ & -21 & -54 & -26 & -38 & -26 & -23 & 0 & -21 & -46 & -17 & 21 & 0.75 & 0.13 & 0.62 \\
\hline His & -2.1 & -6.6 & -5.0 & -7.5 & -0.2 & -1.5 & -1.2 & -3.2 & -8.1 & -5.3 & 3.0 & 0.80 & 0.12 & 0.86 \\
\hline Ile & -2.6 & -3.1 & -0.9 & 0.3 & -1.9 & 4.8 & 5.6 & -3.1 & -5.5 & -2.1 & 3.1 & 0.47 & 0.01 & 0.42 \\
\hline Leu & -2.1 & -8.4 & 0.7 & -3.2 & -2.6 & 0.5 & 7.9 & 0.4 & -3.6 & 1.4 & 4.9 & 0.56 & 0.15 & 0.45 \\
\hline Lys & -2.5 & -6.1 & -1.9 & -3.1 & -3.4 & -2.4 & -1.2 & -1.7 & -3.5 & -3.7 & 2.9 & 0.90 & 0.63 & 0.76 \\
\hline Met & -1.9 & $-6.5^{\mathrm{A}}$ & $-3.3^{\mathrm{B}}$ & $-3.9^{\mathrm{AB}}$ & -2.1 & -3.0 & -2.5 & -2.7 & -3.9 & -2.2 & 0.8 & 0.38 & 0.01 & 0.07 \\
\hline Phe & -6.1 & -10.6 & -10.8 & -10.7 & -8.9 & -11.0 & -12.3 & -11.0 & -16.1 & -12.9 & 2.3 & 0.64 & 0.21 & 0.54 \\
\hline Thr & -2.9 & -7.1 & -6.4 & -7.9 & -5.6 & -6.6 & -4.4 & -2.3 & -8.1 & -1.9 & 3.6 & 0.81 & 0.50 & 0.84 \\
\hline Trp & -0.7 & -1.5 & -0.7 & -0.3 & -1.1 & -1.3 & 0.4 & -1.4 & -1.8 & 0.1 & 0.7 & 0.10 & 0.79 & 0.83 \\
\hline Val & -0.6 & -4.1 & 1.7 & -1.8 & 0.0 & -2.4 & 7.2 & 4.1 & 4.3 & 9.4 & 5.2 & 0.63 & 0.18 & 0.64 \\
\hline Non-EAA & -5 & -173 & -78 & -164 & -157 & -207 & -140 & -138 & -203 & -223 & 40 & 0.89 & 0.44 & 0.15 \\
\hline Ala & -21 & -59 & -51 & -58 & -49 & -51 & -51 & -54 & -53 & -51 & 9 & 0.95 & 0.52 & 0.91 \\
\hline Asn & -2 & -18 & -12 & -14 & -35 & -10 & -20 & 0 & -10 & -21 & 7 & 0.50 & 0.13 & 0.07 \\
\hline Asp & 0.4 & -0.3 & 1.1 & 0.1 & 1.0 & 0.7 & -0.6 & 1.0 & 0.2 & -0.4 & 0.5 & 0.19 & 0.97 & 0.11 \\
\hline Cys & -2.0 & -1.4 & -1.0 & -2.7 & 0.7 & -4.8 & 0.0 & -6.0 & -6.4 & -3.5 & 4.4 & 0.89 & 0.46 & 0.88 \\
\hline Gln & 23 & -17 & 44 & 0.5 & -9 & -64 & -10 & 8 & 51 & -21 & 42 & 0.63 & 0.79 & 0.75 \\
\hline Glu & 30 & 19 & 37 & 29 & 23 & 24 & 31 & 22 & 22 & 24 & 5 & 0.34 & 0.34 & 0.17 \\
\hline Gly & -23 & -59 & -51 & -80 & -53 & -55 & -46 & $-61^{\mathrm{a}}$ & $-59^{\mathrm{a}}$ & $-97^{\mathrm{b}}$ & 10 & 0.03 & 0.06 & 0.28 \\
\hline Pro & -3.1 & -8.2 & -7.0 & -9.0 & -7.5 & -8.1 & -6.2 & -6.2 & -13.8 & -9.1 & 3.6 & 0.80 & 0.73 & 0.81 \\
\hline Ser & -11 & -22 & -30 & -23 & -24 & -30 & -30 & -33 & -36 & -37 & 6 & 0.77 & 0.03 & 0.79 \\
\hline Tyr & -6.2 & -6.7 & -8.3 & -7.1 & -8.2 & -8.8 & -5.9 & -10.2 & -11.8 & -7.8 & 1.7 & 0.35 & 0.15 & 0.81 \\
\hline Total AA & -24 & -227 & -104 & -202 & -186 & -230 & -140 & -161 & -232 & -240 & 53 & 0.97 & 0.65 & 0.13 \\
\hline \multicolumn{15}{|c|}{ Whole blood flux } \\
\hline $\mathrm{O}_{2}$ & $-1,416$ & $-1,981$ & $-2,114$ & $-2,306$ & $-2,070$ & $-2,308$ & $-2,390$ & $-2,118$ & $-2,544$ & $-2,911$ & 200 & 0.36 & $<0.01$ & 0.13 \\
\hline $\mathrm{CO}_{2}$ & 713 & 987 & 1,319 & 1,253 & 1,371 & 1,226 & 1,344 & 1,288 & 1,590 & 1,474 & 255 & 0.86 & 0.24 & 0.72 \\
\hline Propionate & -440 & -462 & -482 & -607 & -560 & -693 & -513 & -780 & -752 & -593 & 86 & 0.60 & 0.08 & 0.24 \\
\hline Ammonia & -285 & -285 & -268 & -328 & -219 & -260 & -264 & -286 & -327 & -349 & 39 & 0.58 & 0.02 & 0.85 \\
\hline Urea & 193 & $257^{\mathrm{AB}}$ & $206^{\mathrm{A}}$ & $300^{\mathrm{B}}$ & 226 & 248 & 241 & 299 & 292 & 337 & 29 & 0.15 & 0.01 & 0.49 \\
\hline
\end{tabular}

$\stackrel{M}{\equiv}$ A,B Signify the Fisher least significant difference test for treatment to affect prepartum to 4 DIM changes $(P \leq 0.05)$.

$\underset{\mathcal{C}}{\mathrm{a}, \mathrm{b}}$ Within a row and within DIM, LSM with different superscript lowercase letters are significantly different $(P \leq 0.05)$.

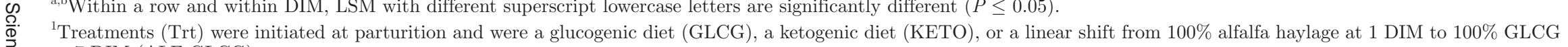
at 7 DIM (ALF-GLCG).

$\quad{ }^{2}$ Standard error of the mean $(\mathrm{n}=2)$

${ }^{3}$ Fixed effects for postpartum observations (treatments initiated at parturition).

号 ${ }^{4} \mathrm{EAA}=$ essential AA. 

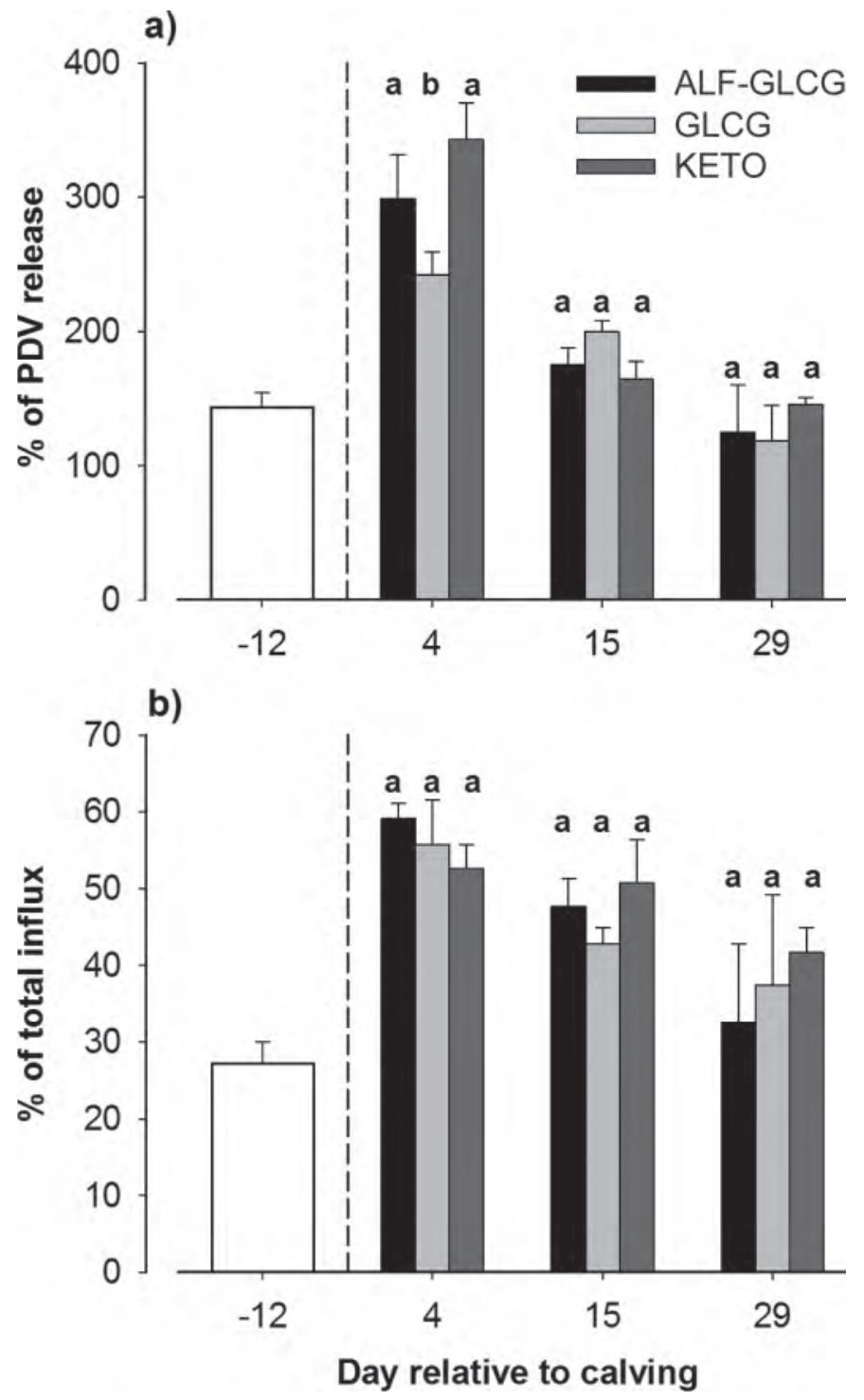

Figure 2. Hepatic removal of lactate as percentage of net portaldrained visceral (PDV) release (a) and of total hepatic influx (b). Prepartum, bar is the mean of 8 observations $\pm \mathrm{SE}$; postpartum, each bar is the mean of $3[n=2$ with the glucogenic diet (GLCG)] observations \pm SE. The hepatic removal of lactate increased from prepartum to 4 DIM $(P<0.01)$ as percentage of both PDV release and of total influx. Postpartum, the hepatic removal of lactate as percentage of PDV release was less with GLCG than with the ketogenic diet (KETO) and the diet with $100 \%$ alfalfa haylage on the day of parturition, followed by a 6 -d gradual shift to the GLCG diet (ALF-GLC) at 4 DIM, but did not differ at 15 and 29 DIM (interaction, $P=0.02$ ). The hepatic removal of lactate as percentage of total influx was unaffected by postpartum treatments $(P=0.78)$, but decreased as lactation progressed $(P<0.01)$

starch increased from the prepartum level to $28 \pm 3 \%$ with KETO when shifting starch source to $\mathrm{NaOH}-$ treated wheat grain at a similar starch intake. This value is in good agreement with the small intestinal starch digestibility for $\mathrm{NaOH}$-treated wheat measured in duodenal- and ileal-fistulated lactating dairy cows
(Larsen et al., 2009). However, the portal recovery of starch from $\mathrm{NaOH}$-treated wheat was substantially lower (10 to $15 \%$ ) with ALF-GLCG and GLCG, where starch intake increased to more than $6 \mathrm{~kg} / \mathrm{d}$. Newly absorbed glucose can be metabolized to L-lactate and Ala by the enterocytes and, thus, potentially mask the increment in PDV glucose release; nevertheless, the net portal release of L-lactate has been unaffected in studies with glucose infusion to the duodenum (Krehbiel et al., 1996) or abomasum (Larsen and Kristensen, 2009b). Thus, a smaller proportion of starch intake was likely digested in the small intestine with high intake of starch with presumably low ruminal degradability, but to what extent this was related to low small intestinal digestibility cannot be concluded with certainty from this experiment, as actual rumen outflows were unknown. The increased net PDV release of glucose did not affect the hepatic release of glucose, indicating that no counteracting hepatic glucose metabolism occurred in response to increased PDV glucose release. This is consistent with other experiments with dairy cows (Reynolds et al., 1998; Larsen and Kristensen, 2009b) and steers (Harmon et al., 2001). Hence, the additionally absorbed glucose from the small intestine with ALF-GLCG and GLCG was efficiently transferred to peripheral tissues.

At 4 DIM, glucose supply from exogenous origin did not differ between GLCG and KETO when assessed as the sum of small intestinal absorption (e.g., corrected PDV flux of glucose) and the hepatic release of glucose attributed to hepatic propionate removal. Even so, with GLCG, small intestinal glucose absorption contributed $40 \%$ to the exogenous glucose supply as compared with $27 \%$ with KETO, equivalent to approximately 1 and $0.5 \mathrm{~kg} / \mathrm{d}$ of starch being digested in the small intestine, respectively. The calculation does not comprise all exogenous glucogenic carbon; however, lactate from rumen epithelial metabolism of propionate is of minor importance (Kristensen, 2005), PDV release of isobutyrate and valerate is generally limited (Reynolds et al., 2003; Larsen and Kristensen, 2009a), and glucogenic AA are likely not of quantitative importance (discussed later). In spite of the exogenous glucose supply not differing between GLCG and KETO, adaptation of nutrient metabolism to lactation seemed to be associated with the least metabolic stress with the GLCG diet, as judged from the lowest dependency on interorgan Cori cycling of glucogenic carbon via lactate at 4 DIM (Figure 2a). Moreover, it was interesting that milk lactose concentration with GLCG at 4 DIM was greater (4.8 $\mathrm{g} / \mathrm{kg}$ ) compared with concentrations usually observed at 4 DIM (4.5 g/kg; Larsen and Kristensen, 2010; Dalbach et al., 2011), and with ALF-GLCG and KETO. Therefore, the current experiment pointed toward the 
Table 7. Net splanchnic metabolite fluxes $(\mathrm{mmol} / \mathrm{h})^{1}$

\begin{tabular}{|c|c|c|c|c|c|c|c|c|c|c|c|c|c|c|}
\hline \multirow[b]{2}{*}{ Item } & \multirow[b]{2}{*}{ Prepartum } & \multicolumn{3}{|c|}{4 DIM } & \multicolumn{3}{|c|}{15 DIM } & \multicolumn{3}{|c|}{29 DIM } & \multirow[b]{2}{*}{$\mathrm{SEM}^{2}$} & \multicolumn{3}{|c|}{$P$-value ${ }^{3}$} \\
\hline & & $\begin{array}{l}\text { ALF- } \\
\text { GLCG }\end{array}$ & GLCG & KETO & $\begin{array}{l}\text { ALF- } \\
\text { GLCG }\end{array}$ & GLCG & KETO & $\begin{array}{l}\text { ALF- } \\
\text { GLCG }\end{array}$ & GLCG & KETO & & Trt & DIM & $\begin{array}{c}\text { Trt } \times \\
\text { DIM }\end{array}$ \\
\hline \multicolumn{15}{|l|}{ Plasma flux } \\
\hline Glucose & 288 & $463^{\mathrm{a}}$ & $607^{\mathrm{ab}}$ & $625^{\mathrm{b}}$ & 580 & 680 & 525 & $798^{\mathrm{a}}$ & $768^{\mathrm{ab}}$ & $636^{\mathrm{b}}$ & 45 & 0.39 & $<0.01$ & $<0.01$ \\
\hline L-Lactate & -32 & $-182^{\mathrm{a}}$ & $-140^{\mathrm{a}}$ & $-248^{\mathrm{b}}$ & -79 & -98 & -80 & -26 & -39 & -74 & 19 & 0.22 & $<0.01$ & 0.03 \\
\hline Glycerol & -8 & -37 & -28 & -28 & -23 & -22 & -27 & -10 & -15 & -24 & 5 & 0.77 & 0.05 & 0.54 \\
\hline $\mathrm{EAA}^{4}$ & 46 & 43 & 151 & 108 & 152 & 184 & 156 & 214 & 234 & 192 & 22 & 0.13 & $<0.01$ & 0.36 \\
\hline His & 1.5 & $-3.7^{\mathrm{A}, \mathrm{a}}$ & $4.3^{\mathrm{B}, \mathrm{b}}$ & $0.9^{\mathrm{AB}, \mathrm{ab}}$ & 8.9 & 7.1 & 3.7 & 10.6 & 8.2 & 7.8 & 1.6 & 0.37 & $<0.01$ & 0.04 \\
\hline Ile & 7 & 9 & 25 & 19 & 22 & 31 & 24 & 28 & 33 & 27 & 4 & 0.16 & 0.02 & 0.64 \\
\hline Leu & 10 & $14^{\mathrm{A}}$ & $42^{\mathrm{B}}$ & $30^{\mathrm{AB}}$ & 39 & 50 & 43 & 55 & 60 & 53 & 6 & 0.17 & $<0.01$ & 0.50 \\
\hline Lys & 10.7 & 8.1 & 21.8 & 17.0 & 19.1 & 32.9 & 23.1 & 30.8 & 34.0 & 24.6 & 3 & 0.08 & $<0.01$ & 0.28 \\
\hline Met & 1.7 & $-0.6^{\mathrm{A}, \mathrm{a}}$ & $5.5^{\mathrm{B}, \mathrm{b}}$ & $3.1^{\mathrm{B}, \mathrm{c}}$ & 6.5 & 8.4 & 6.7 & 8.9 & 10.2 & 8.2 & 1 & 0.01 & $<0.01$ & 0.07 \\
\hline Phe & 0.9 & 0.8 & 9.9 & 6.8 & 13.1 & 12.5 & 8.8 & 16.3 & 16.4 & 12.1 & 2 & 0.36 & $<0.01$ & 0.14 \\
\hline Thr & 3.8 & 3.8 & 12.9 & 8.3 & 12.5 & 12.1 & 15.0 & 21.8 & 21.2 & 23.0 & 3 & 0.49 & $<0.01$ & 0.40 \\
\hline Trp & 0.7 & 0.7 & 2.3 & 1.9 & 2.5 & 2.3 & 1.9 & 2.1 & 3.4 & 1.1 & 1 & 0.34 & 0.57 & 0.32 \\
\hline Val & 8.6 & 10.7 & 26.5 & 19.7 & 28.7 & 29.0 & 30.0 & 40.7 & 48.4 & 34.8 & 4 & 0.26 & $<0.01$ & 0.32 \\
\hline Non-EAA & 22 & -39 & 66 & 13 & 50 & 58 & 76 & 141 & 130 & 77 & 36 & 0.66 & 0.02 & 0.24 \\
\hline Ala & 1 & $-28^{\mathrm{A}}$ & $5^{\mathrm{B}}$ & $-9^{\mathrm{AB}}$ & 18 & 23 & 13 & 26 & 33 & 24 & 6 & 0.16 & $<0.01$ & 0.08 \\
\hline Asn & 4.5 & 5.0 & 2.9 & 16.7 & -1.8 & 7.4 & 7.7 & 19.5 & -5.6 & 8.0 & 8.6 & 0.64 & 0.91 & 0.47 \\
\hline Asp & 1.1 & $0.4^{\mathrm{A}, \mathrm{a}}$ & $2.6^{\mathrm{B}, \mathrm{b}}$ & $2.4^{\mathrm{B}, \mathrm{b}}$ & 2.1 & 2.7 & 1.5 & 2.9 & 2.7 & 1.6 & 0.5 & 0.22 & 0.54 & 0.05 \\
\hline Cys & -1.2 & 1.7 & 3.0 & -0.7 & 3.8 & -0.7 & -4.0 & 0.0 & 1.6 & -0.4 & 3.2 & 0.59 & 0.72 & 0.78 \\
\hline Gln & -1 & 0 & 27 & 4.7 & 1 & -18 & 29 & 43 & 106 & 35 & 31 & 0.83 & 0.04 & 0.21 \\
\hline Glu & 25 & $20^{\mathrm{A}}$ & $39^{\mathrm{B}}$ & $33^{\mathrm{A}}$ & 26 & 31 & 34 & 30 & 29 & 29 & 4 & 0.23 & 0.72 & 0.09 \\
\hline Gly & -10 & -40 & -40 & -58 & -26 & -24 & -31 & $-18^{\mathrm{a}}$ & $-14^{\mathrm{a}}$ & $-45^{\mathrm{b}}$ & 6 & $<0.01$ & $<0.01$ & 0.59 \\
\hline Pro & 1 & 2 & 11 & 8 & 12 & 18 & 14 & 17 & 17 & 14 & 3 & 0.25 & 0.01 & 0.56 \\
\hline Ser & 1.4 & -2.8 & 5.6 & 7.9 & 6.4 & 7.4 & 2.4 & 8.8 & 9.0 & -0.1 & 4.9 & 0.81 & 0.84 & 0.28 \\
\hline Tyr & 0.3 & 3.5 & 9.4 & 7.2 & 8.5 & 11.4 & 10.2 & 11.5 & 15.1 & 10.8 & 1.5 & 0.17 & 0.01 & 0.55 \\
\hline Total AA & 70 & 4 & 217 & 120 & 207 & 243 & 232 & 360 & 339 & 269 & 52 & 0.42 & $<0.01$ & 0.15 \\
\hline \multicolumn{15}{|c|}{ Whole blood flux } \\
\hline $\mathrm{O}_{2}$ & $-3,042$ & $-3,506$ & $-4,265$ & $-4,058$ & $-3,900$ & $-4,704$ & $-4,806$ & $-4,544$ & $-4,739$ & $-5,507$ & 265 & 0.27 & $<0.01$ & $<0.01$ \\
\hline $\mathrm{CO}_{2}$ & 2,724 & $2,695^{\mathrm{A}}$ & $3,666^{\mathrm{B}}$ & $3,298^{\mathrm{B}}$ & 3,208 & 4,315 & 4,424 & 4,091 & 4,050 & 5,105 & 349 & 0.29 & $<0.01$ & $<0.01$ \\
\hline Propionate & 29 & 26 & 45 & 41 & 56 & 66 & 63 & 86 & 67 & 39 & 12 & 0.62 & 0.08 & 0.28 \\
\hline Ammonia & -8.6 & -28.6 & -24.2 & -14.9 & -7.9 & 8.6 & 2.3 & 6.9 & 4.6 & -3.5 & 5.9 & 0.86 & $<0.01$ & 0.15 \\
\hline Urea & 101 & 143 & 100 & 94 & 124 & 92 & 66 & 129 & 119 & 124 & 24 & 0.33 & 0.32 & 0.86 \\
\hline
\end{tabular}

A,B Signify the Fisher least significant difference test for treatment to affect prepartum to 4 DIM changes $(P \leq 0.05)$.

$\infty{ }^{\mathrm{a}-c}$ Within a row and within DIM, LSM with different superscript lowercase letters are significantly different $(P \leq 0.05)$.

$\stackrel{\frac{\Gamma}{\Phi}}{\frac{1}{D}}{ }^{1}$ Treatments (Trt) were initiated at parturition and were glucogenic feeding (GLCG), ketogenic feeding (KETO), or a gradual shift from $100 \%$ alfalfa haylage at 1 DIM to $100 \%$ GLCG at 7 DIM (ALF-GLCG).

${ }^{2}$ Standard error of the mean $(\mathrm{n}=3)$.

${ }^{3}$ Fixed effects for postpartum observations (treatments initiated at parturition)

兒 $\quad{ }^{4} \mathrm{EAA}=$ essential AA. 
possibility of enhancing the glucogenic status of postpartum transition cows using the GLCG diet; however, not to the extent observed with abomasal infusion of glucose (Larsen and Kristensen, 2009b).

\section{Interaction Between Splanchnic Glucose and AA Metabolism}

The potential for sparing AA from PDV catabolism by exploiting the metabolic flexibility of enterocytes in substrate utilization observed in vitro (Okine et al., 1995; Oba et al., 2004) is often put forward as a potential benefit of increasing ruminal escape starch (Freetly et al., 2010); however, in vivo investigations of this substrate interaction are rare. In the present experiment, the increased net portal release of EAA with GLCG was not reflected in the net splanchnic release of EAA despite the net hepatic fluxes of EAA being unaffected by treatments. The reason for this discrepancy is unknown and may be related to the reduced number of observations with GLCG for PDV and hepatic fluxes $(\mathrm{n}=2)$. Using short-term abomasal infusion of protein alone or combined with glucose in sheep, the net portal release of AA was unaffected by the presence of glucose in the infusate (Freetly et al., 2010). Increasing the AA supply to the small intestine has not been found to affect the PDV metabolism of glucose in dairy cows (Galindo et al., 2011) and sheep (El-Kadi et al., 2006).

The hepatic removal of EAA and non-EAA was generally unaffected by the different glucogenic status induced by postpartum feeding strategies. The hepatic removal of His, Met, Phe, Thr, and Trp increased from prepartum to 4 DIM, whereas the hepatic removal of Ile, Leu, Lys, and Val were unaffected by transition to lactation. The extent to which the increased hepatic removal of His, Met, Phe, Thr, and Trp was catabolized and used for gluconeogenesis is unknown. However, assuming that the entire hepatic removal of these EAA is utilized for gluconeogenesis, these could maximally account for $1.9,2.8,1.8$, and $1.9 \pm 0.4 \%$ (means \pm $\mathrm{SE}$ ) of the net hepatic glucose release at $-12,4,15$, and 29 DIM, respectively, in agreement with our previous observations with periparturient cows (Larsen and Kristensen, 2009a). Further, considering the number of other metabolic pathways utilizing EAA for anabolic purposes, for example synthesis of export proteins (Bell, 1995; Danfær et al., 1995) and postpartum liver growth (Gibb et al., 1992; Reynolds et al., 2004), these relatively low maximal contribution rates indicate that the true contribution to gluconeogenesis was limited and of negligible quantitative importance to the postpartum transition cow.

As previously observed with transition cows (Larsen and Kristensen, 2009a; Dalbach et al., 2011), hepatic removal of Ala, Gly, and Ser increased from prepartum to 4 DIM in the present experiment. The contribution of these non-EAA to hepatic gluconeogenesis could be of quantitative importance to the transition cow, but the true contribution is unknown. In liver slices from sheep, the conversion of Ala to glucose was observed to increase more compared with the conversion of propionate to glucose when a hypoglycemic condition was induced (Overton et al., 1999). A compilation of tracer studies with fed sheep showed that of Ala, Gly, and Ser, only Ala contributed substantially to gluconeogenesis (Bergman and Heitmann, 1978). These observations taken together suggest that only Ala contributes substantially to gluconeogenesis in the postpartum transition cow.

Overall, the present data do not support the hypothesis that the rapid postpartum increase in net hepatic release of glucose is supported by increased utilization of AA for gluconeogenesis. The immediate postpartum increased hepatic glucose release seems supported by an endogenous recycling of glucogenic carbon mediated by a dual mode adaptation of glucose metabolism at the level of liver and at the level peripheral tissues. Also, glycogenolysis in the early postpartum transition period might be of importance, but this has not been assessed in the present study. At the liver level, the affinity for lactate uptake was upregulated rapidly after calving, as indicated by the general increase in hepatic fractional removal of total lactate influx (Figure 2b) and investigations of gene expression and activity of pyruvate carboxylase activity in liver biopsies (Greenfield et al., 2000; Velez and Donkin, 2005). At the level of peripheral tissue, glucose metabolism seems to be partly shifted from complete oxidation to Cori cycling, returning glucose carbon to the liver in postpartum transition dairy cows (Figure 2a), as also proposed by Reynolds et al. (2003). Studies of irreversible loss rates of glucose during the transition to lactation support the Cori cycling dependency, as the glucose irreversible loss rate corrected for loss via lactose has been observed to decrease at the initiation of lactation (Bennink et al., 1972; Baird et al., 1983; M. Larsen and N. B. Kristensen, unpublished data).

\section{Effects of Diets on Metabolic Status}

The ALF-GLCG and KETO diets induced hypoglycemic/hyperketonemic conditions in 2 distinct ways. With ALF-GLCG, the condition was likely induced by high lipid mobilization and low feed intake in the early postpartum transition period, whereas the condition with KETO was likely induced by ruminal fermentation of sugars from fodder beets. Adding 4.7\% sucrose to a postpartum transition diet, Penner and Oba (2009) 
also observed the circulating concentrations of glucose and BHBA responding in the direction of hypoglycemic/hyperketonemic conditions, even though dietary sugar levels were substantially lower than in the present study.

Ruminal fiber priming diets for postpartum transition cows are often used in North America (Shaver, 1997; Drackley et al., 2005) and Denmark (Larsen and Kristensen, 2010). The extent of metabolic stress with the ALF-GLCG treatment due to low feed intake was evident from low net PDV release of nutrients, low hepatic release of glucose, and low net splanchnic release of nutrients. We are aware of only a few studies investigating the effects of ruminal fiber priming diets for postpartum transition cows (Rabelo et al., 2005; Guo et al., 2007; Larsen and Kristensen, 2010). Overall, the present study investigating splanchnic metabolism and published production trials with special transition TMR providing additional ruminal fiber give no evidence of positive metabolic effects of providing additional fiber at the expense of glucogenic substrate to transition dairy cows.

\section{CONCLUSIONS}

The glucogenic feeding strategy based on feeding $\mathrm{NaOH}$-treated wheat grain to postpartum transition cows induced the highest glucogenic status among the tested feeding strategies. This was obtained by greater release of glucose from PDV, splanchnic tissues, and the lowest dependency on Cori cycling of glucogenic carbon via lactate. However, the portal recovery of dietary starch decreased with high inclusion of $\mathrm{NaOH}-$ treated wheat grain. The immediate postpartum high allowance of alfalfa haylage provided the lowest amount of nutrients from the splanchnic tissues, inducing low glucogenic status. Glucogenic AA, apart from Ala, were not of quantitative importance for liver gluconeogenesis in postpartum transition cows. Salvaging glucogenic carbon by return of lactate from peripheral tissues to the liver is apparently an important adaptive response to low glucogenic status of postpartum transition dairy cows.

\section{ACKNOWLEDGMENTS}

We gratefully acknowledge department staff Anne Krustrup, Birgit H. Løth, Marie Engbæk, Ole H. Olsen, Pia Jensen, and Torkild N. Jakobsen (all of Aarhus University, Tjele, Denmark) for skillful and dedicated technical assistance during surgery, care of animals, samplings, and laboratory analyses. We thank the department barn staff for their hard work and skillful assistance. Funding was provided by The
Danish AgriFish Agency (Copenhagen, Denmark; no. 3412-10-02814), the Danish Cattle Federation (Aarhus Denmark), and the Ministry of Food, Agriculture, and Fisheries (Copenhagen, Denmark).

\section{REFERENCES}

Baird, G. D., J. G. Van Der Walt, and E. N. Bergman. 1983. Wholebody metabolism of glucose and lactate in productive sheep and cows. Br. J. Nutr. 50:249-265.

Bell, A. W. 1995. Regulation of organic nutrient metabolism during transition from late pregnancy to early lactation. J. Anim. Sci. 73:2804-2819.

Bennink, M. R., R. W. Mellenberger, R. A. Frobish, and D. E. Bauman. 1972. Glucose oxidation and entry rate as affected by initiation of lactation. J. Dairy Sci. 55(Suppl. 1):172-173.

Bergman, E. N., and R. N. Heitmann. 1978. Metabolism of amino acids by gut, liver, kidneys, and peripheral tissues. Fed. Proc. 37:1228-1232.

Calder, A. G., K. E. Garden, S. E. Anderson, and G. E. Lobley. 1999. Quantitation of blood and plasma amino acids using isotope dilution electron impact gas chromatography/mass spectrometry with $\mathrm{U}-{ }^{13} \mathrm{C}$ amino acids as internal standards. Rapid Commun. Mass Spectrom. 13:2080-2083.

Dalbach, K. F., M. Larsen, B. M. L. Raun, and N. B. Kristensen. 2011. Effects of supplementation with 2-hydroxy-4-(methylthio)butanoic acid isopropyl ester on splanchnic amino acid metabolism and essential amino acid mobilization in postpartum transition Holstein cows. J. Dairy Sci. 94:3913-3927.

Danfær, A., V. Tetens, and N. Agergaard. 1995. Review and an experimental study on the physiological and quantitative aspects of gluconeogenesis in lactating ruminants. Comp. Biochem. Physiol. B Biochem. Mol. Biol. 111:201-210.

Drackley, J. K., H. M. Dann, G. N. Douglas, N. A. J. Guretzky, N. B Litherland, J. P. Underwood, and J. J. Loor. 2005. Physiological and pathological adaptations in dairy cows that may increase susceptibility to periparturient diseases and disorders. Ital. J. Anim. Sci. 4:323-344.

Drackley, J. K., T. R. Overton, and G. N. Douglas. 2001. Adaptations of glucose and long-chain fatty acid metabolism in liver of dairy cows during the periparturient period. J. Dairy Sci. 84(E. Suppl.):E100-E112.

El-Kadi, S. W., R. L. Baldwin, N. E. Sunny, S. L. Owens, and B. J. Bequette. 2006. Intestinal protein supply alters amino acid, but not glucose, metabolism by the sheep gastrointestinal tract. J. Nutr. 136:1261-1269.

Ferguson, J. D., D. T. Galligan, and N. Thomsen. 1994. Principal descriptors of body condition score in Holstein cows. J. Dairy Sci. 77:2695-2703.

Freetly, H. C., C. L. Ferrell, and S. Archibeque. 2010. Net flux of amino acids across the portal-drained viscera and liver of the ewe during abomasal infusion of protein and glucose. J. Anim. Sci. 88:1093-1107.

Galindo, C. E., D. R. Ouellet, D. Pellerin, S. Lemosquet, I. OrtiguesMarty, and H. Lapierre. 2011. Effect of amino acid or casein supply on whole-body, splanchnic, and mammary glucose kinetics in lactating dairy cows. J. Dairy Sci. 94:5558-5568.

Gibb, M. J., W. E. Ivings, M. S. Dhanoa, and J. D. Sutton. 1992. Changes in body components of autumn-calving Holstein-Friesian cows over the first 29 weeks of lactation. Anim. Prod. 55:339-360.

Greenfield, R. B., M. J. Cecava, and S. S. Donkin. 2000. Changes in mRNA expression for gluconeogenic enzymes in liver of dairy cattle during the transition to lactation. J. Dairy Sci. 83:1228-1236.

Grummer, R. R. 1995. Impact of changes in organic nutrient metabolism on feeding the transition dairy cow. J. Anim. Sci. 73:28202833.

Guo, J., R. R. Peters, and R. A. Kohn. 2007. Effect of a transition diet on production performance and metabolism in periparturient dairy cows. J. Dairy Sci. 90:5247-5258. 
Harmon, D. L., C. J. Richards, K. C. Swanson, J. A. Howell, J. C. Matthews, A. D. True, G. B. Huntington, S. A. Gahr, and R. W. Russel. 2001. Influence of ruminal or postruminal starch on visceral glucose metabolism in steers. Pages 273-276 in Energy Metabolism in Animals. EAAP Publication No. 103. A. Chwalibog and K. Jakobsen, ed. Wageningen Press, Wageningen, the Netherlands.

Harmon, D. L., R. M. Yamka, and N. A. Elam. 2004. Factors affecting intestinal starch digestion in ruminants: A review. Can. J. Anim. Sci. 84:309-318.

Harvey, R. B., and A. J. Brothers. 1962. Renal extraction of para-aminohippurate and creatine measured by continuous in vivo sampling of arterial and renal-vein blood. Ann. N. Y. Acad. Sci. 102:46-54.

Jensen, C., M. R. Weisbjerg, P. Nørgaard, and T. Hvelplund. 2005. Effect of maize silage maturity on site of starch and NDF digestion in lactating dairy cows. Anim. Feed Sci. Technol. 118:279-294.

Krehbiel, C. R., R. A. Britton, D. L. Harmon, J. P. Peters, R. A. Stock, and H. E. Grotjan. 1996. Effects of varying levels of duodenal or midjejunal glucose and 2-deoxyglucose infusion on small intestinal disappearance and net portal glucose flux in steers. J. Anim. Sci. 74:693-700.

Kristensen, N. B. 2000. Quantification of whole blood short-chain fatty acids by gas chromatographic determination of plasma 2-chloroethyl derivatives and correction for dilution space in erythrocytes. Acta Agric. Scand. A Anim. Sci. 50:231-236.

Kristensen, N. B. 2005. Splanchnic metabolism of volatile fatty acids in the dairy cow. Anim. Sci. 80:3-10.

Kristensen, N. B., A. C. Storm, and M. Larsen. 2010. Effect of dietary nitrogen content and intravenous urea infusion on ruminal and portal-drained visceral extraction of arterial urea in lactating Holstein cows. J. Dairy Sci. 93:2670-2683.

Kristensen, N. B., A. C. Storm, B. M. L. Raun, B. A. Røjen, and D. L. Harmon. 2007. Metabolism of silage alcohols in lactating dairy cows. J. Dairy Sci. 90:1364-1377.

Larsen, M., and N. B. Kristensen. 2009a. Effect of abomasal glucose infusion on splanchnic amino acid metabolism in periparturient dairy cows. J. Dairy Sci. 92:3306-3318.

Larsen, M., and N. B. Kristensen. 2009b. Effect of abomasal glucose infusion on splanchnic and whole body glucose metabolism in periparturient dairy cows. J. Dairy Sci. 92:1071-1083.

Larsen, M., and N. B. Kristensen. 2010. Effect of a lucerne feeding strategy in the first week postpartum on feed intake and ketone body profiles in blood plasma, urine, and milk in Holstein cows. Acta Agric. Scand. A Anim. Sci. 60:239-249.

Larsen, M., P. Lund, M. R. Weisbjerg, and T. Hvelplund. 2009. Digestion site of starch from cereals and legumes in lactating dairy cows. Anim. Feed Sci. Technol. 153:236-248.

Løvendahl, P., and H. M. Purup. 2002. Technical note: Time-resolved fluoro-immunometric assay for intact insulin in livestock species. J. Anim. Sci. 80:191-195.

Marsh, W. H., B. Fingerhut, and H. Miller. 1965. Automated and manual direct methods for the determination of blood urea. Clin. Chem. 11:624-627.

Nocek, J. E., and S. Tamminga. 1991. Site of digestion of starch in the gastrointestinal tract of dairy cows and its effect on milk yield and composition. J. Dairy Sci. 74:3598-3629.

Oba, M., R. L. Baldwin VI, and B. J. Bequette. 2004. Oxidation of glucose, glutamate, and glutamine by isolated ovine enterocytes in vitro is decreased by the presence of other metabolic fuels. J. Anim. Sci. 82:479-486.
Okine, E. K., D. R. Glimm, J. R. Thompson, and J. J. Kennelly. 1995. Influence of stage of lactation on glucose and glutamine metabolism in isolated enterocytes from dairy cattle. Metabolism 44:325-331.

Overton, T. R. 1998. Substrate utilization for hepatic gluconeogenesis in the transition dairy cow. Pages 237-246 in Proc. 1998 Cornell Nutr. Conf. Feed Manufacturers. Cornell University, Ithaca, NY.

Overton, T. R., J. K. Drackley, C. J. Ottemann-Abbamonte, A. D. Beaulieu, L. S. Emmert, and J. H. Clark. 1999. Substrate utilization for hepatic gluconeogenesis is altered by increased glucose demand in ruminants. J. Anim. Sci. 77:1940-1951.

Penner, G. B., and M. Oba. 2009. Increasing dietary sugar concentration may improve dry matter intake, ruminal fermentation, and productivity of dairy cows in the postpartum phase of the transition period. J. Dairy Sci. 92:3341-3353.

Phipps, R. H., J. D. Sutton, D. J. Humphries, and A. K. Jones. 2001. A comparison of the effects of cracked wheat and sodium hydroxidetreated wheat on food intake, milk production and rumen digestion in dairy cows given maize silage diets. Anim. Sci. 72:585-594.

Rabelo, E., R. L. Rezende, S. J. Bertics, and R. R. Grummer. 2005. Effects of pre- and postfresh transition diets varying in dietary energy density on metabolic status of periparturient dairy cows. J. Dairy Sci. 88:4375-4383.

Reynolds, C. K., P. C. Aikman, B. Lupoli, D. J. Humphries, and D. E. Beever. 2003. Splanchnic metabolism of dairy cows during the transition from late gestation through early lactation. J. Dairy Sci. 86:1201-1217.

Reynolds, C. K., B. Durst, B. Lupoli, D. J. Humphries, and D. E. Beever. 2004. Visceral tissue mass and rumen volume in dairy cows during the transition from late gestation to early lactation. J. Dairy Sci. 87:961-971.

Reynolds, C. K., D. J. Humphries, S. B. Cammell, J. Benson, J. D. Sutton, and D. E. Beever. 1998. Effects of abomasal wheat starch infusion on splanchnic metabolism and energy balance of lactating dairy cows. Pages 39-42 in Energy Metabolism in Farm Animals. K. J. McCracken, E. F. Unsworth, and A. R. G. Wylie, ed. CAB International., Wallingford, UK.

Røjen, B. A., P. K. Theil, and N. B. Kristensen. 2011. Effect of nitrogen supply on inter-organ fluxes of urea-N and renal urea-N kinetics in lactating Holstein cows. J. Dairy Sci. 94:2532-2544.

Schoorl, N. 1929. Suiker titratie. Chem. Weekbl. 26:130-134.

Shaver, R. D. 1997. Nutritional risk factors in the etiology of left displaced abomasum in dairy cows: A review. J. Dairy Sci. 80:24492453

Sjaunja, L. O., L. Bævre, L. Junkkarinen, J. Pedersen, and J. Setälä. 1991. A Nordic proposal for an energy corrected milk (ECM) formula. Pages 156-157 in Proceedings of the 27th session of International Committee for Recording Productivity of Milk Animals (ICRPMA). EAAP Publication no. 50. EAAP, Wageningen, the Netherlands.

Swaisgood, H. E. 1995. Protein and amino acid composition of bovine milk. Pages 464-468 in Handbook of milk composition. R. G. Jensen, ed. Academic Press Inc., Toronto, Ontario, Canada.

Velez, J. C., and S. S. Donkin. 2005. Feed restriction induces pyruvate carboxylase but not phosphoenolpyruvate carboxykinase in dairy cows. J. Dairy Sci. 88:2938-2948.

Volden, H., ed. 2011. NorFor-The Nordic feed evaluation system. EAAP Publication No. 130. Wageningen Academic Publishers, Wageningen, the Netherlands. 